ROCZNIKI HUMANISTYCZNE

Tom LXIX, zeszyt $2-2021$

DOI: https://doi.org/10.18290/rh21692-5

\title{
SZTUKA W SŁUŻBIE IMPERIUM I NARODU: CASUS BIZANTYJSKICH FRESKÓW W KAPLICY ŚW. TRÓJCY NA ZAMKU LUBELSKIM W ŚWIETLE POGLĄDÓW ROSYJSKICH HISTORYKÓW (XIX - POCZĄTEK XX WIEKU)*
}

\section{POCZĄTKI}

Historia odkrycia bizantyjskich fresków w kaplicy Świętej Trójcy na Zamku Lubelskim ${ }^{1}$ sięga schyłku XIX w. W roku 1897 Józef Smoliński, malarz i kolekcjoner z Lublina, zauważył fragmenty sceny fundacyjnej wyłaniające się spod warstw opadającego tynku². Wcześniej, w latach 1823-1826, Zamek

Dr MAtTeO PICCIN - Università Ca’ Foscari di Venezia; Instytut Komunikacji Specjalistycznej i Interkulturowej Uniwersytetu Warszawskiego; e-mail: m.piccin@uw.edu.pl; ORCID: https://orcid.org/ 0000-0002-9147-4185.

* Główny zrąb niniejszego studium powstał dzięki stypendium im. Hieronima Łopacińskiego, ofiarowanemu przez Collegium Artium i Ośrodek „Brama Grodzka - Teatr NN”. Za cenne wskazówki bibliograficzne i merytoryczne pragnę podziękować: dr. Jackowi Majowi (Collegium Artium), dr Marii M. Przeciszewskiej (Biblioteka Narodowa), prof. Eugeniuszowi Niebelskiemu (Katolicki Uniwersytet Lubelski Jana Pawła II), dr hab. Barbarze Niebelskiej-Rajcy (Katolicki Uniwersytet Lubelski Jana Pawła II) oraz dr hab. Jarosławowi Pietrowowi (Uniwersytet Warszawski).

${ }^{1}$ Kościół murowany na wzgórzu zamkowym powstał w epoce Kazimierza Wielkiego; za czasów Władysława Jagiełły świątynia została nadbudowana, a wnętrze ozdobione przez ruskich malarzy pod kierownictwem mistrza Andrzeja. Napis fundacyjny w kaplicy nosi datę ukończenia prac: 14 sierpnia 1418. A. RÓŻYCKA-BRYZEK, Bizantyńsko-ruskie malowidła w kaplicy zamku lubelskiego (Warszawa: Państwowe Wydawnictwo Naukowe, 1983), 12. O rozszyfrowaniu mocno zniszczonego napisu zob. też Н. Каринский, „Русская надпись в Люблинском тюремском костеле (с 1 рис.)”, w Известия Императорской Археологической Коммиссии, вып. 55-й (Петроград, 1914), 131-135.

2 J. SMoliŃSKI, „Freski w kaplicy zamkowej w Lublinie”, Sprawozdania Komisji do Badania Historii Sztuki w Polsce 7, z. 4 (1905): szp. cclxvii-cclxviii; Opis J. Smolińskiego malowidet, odkrytych przez niego w kościele św. Trójcy na zamku w Lublinie, dn. 12.3.1897 r., aneks w M. WALICKI, „Malowidła ścienne kościoła św. Trójcy na zamku w Lublinie (1418)”, Studia do Dziejów Sztuki w Polsce 3 (1930): 87-89. 
Lubelski przebudowywano na więzienie, zaś jego kaplica pełniła rolę kaplicy więziennej (zob. ilustracja nr 1). Aby dostosować ją do tego celu, wnętrze pokryto wapnem, a w 1890 r. ponownie otynkowano, zacierając przy tym ślady malowideł bizantyjskich ${ }^{3}$.

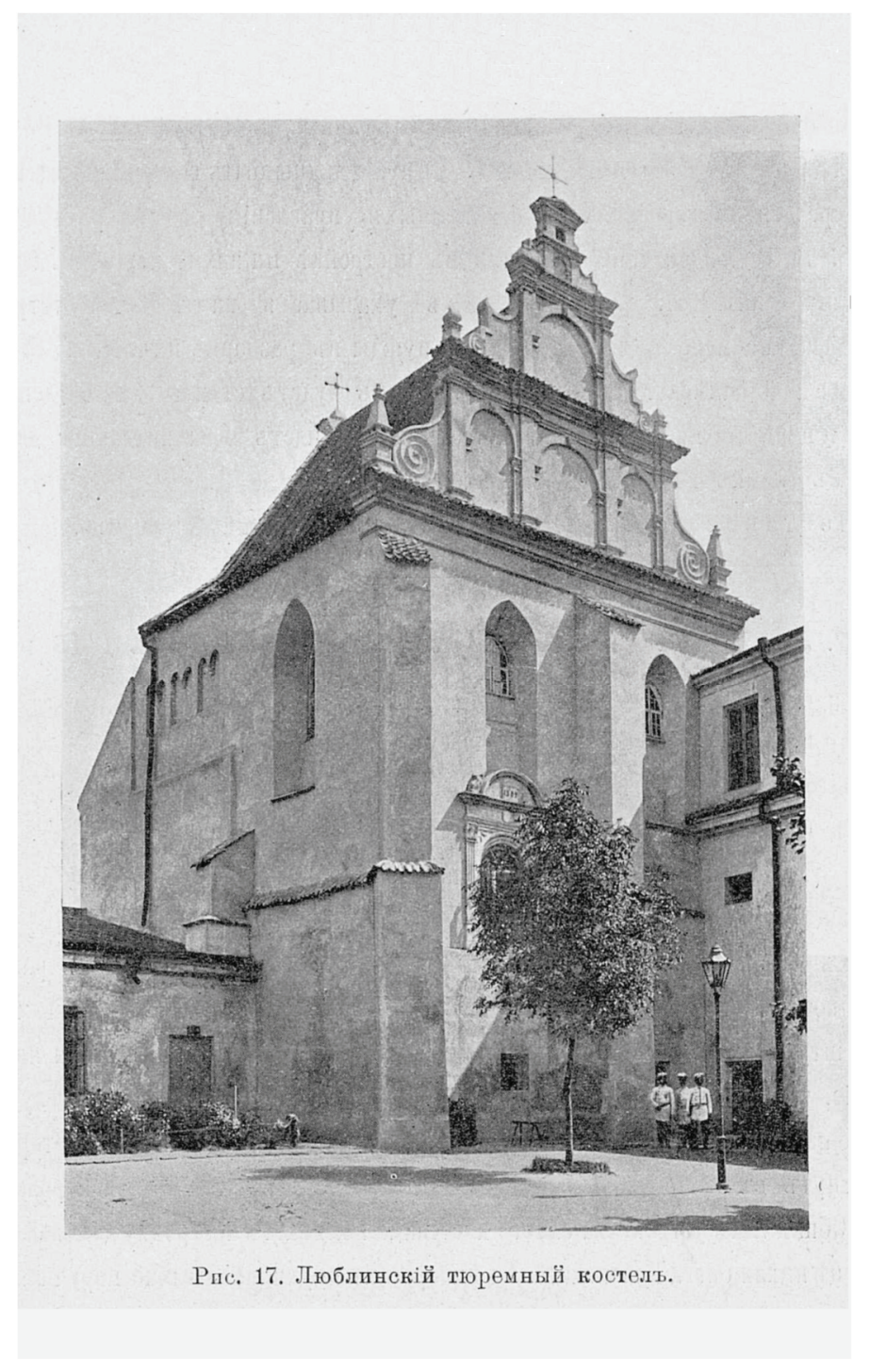

Rysunek 1. Zdjęcie kaplicy Św. Trójcy (więziennej) na Zamku Lubelskim (prawdopodobnie początek XX w.)

\footnotetext{
${ }^{3}$ RÓŻYCKA-BRYZEK, Bizantyńsko-ruskie malowidła, 13.
} 
Pierwsze wzmianki na temat istnienia fresków dał w połowie XIX w. Kazimierz Stronczyński ${ }^{4}$ - wszechstronny uczony, badacz nauk przyrodniczych i historii, znakomity znawca heraldyki i genealogii, uważany za twórcę polskiej numizmatyki, a przede wszystkim zasłużony inwentaryzator zabytków Królestwa Polskiego i „czołowy polski archeolog drugiej połowy XIX wieku”. Opisując kaplicę Świętej Trójcy na łamach urzędowego Dziennika Powszechnego z 21 maja 1863 r., stwierdzał: „odpadła warstwa późniejszego zabielenia pozwala jeszcze widzieć malowidła na ścianach i sklepieniu, zbyt to jednak małe próbki, aby można było z nich odgadnąć przedmiot który przedstawiać miały"6. Uwagom tym nie towarzyszyły jednak żadne inicjatywy restauratorskie $^{7}$. Charakterystyka kaplicy była tylko jednym z wielu fragmentów Opisów zabytków starożytności w Królestwie Polskim, opublikowanych przez Stronczyńskiego w Dzienniku Powszechnym między 1861 a 1863 r., za zgodą Komisji Rządowej Spraw Wewnętrznych i Duchownych. Tekst o kaplicy Świętej Trójcy powstał jako drobna część wielkiej akcji inwentaryzacji zabytków, rozpoczętej na polecenie Namiestnika Królestwa Polskiego Iwana Paskiewicza, którą Stronczyński podjął w latach 1844-1855 jako delegowany wspomnianej Komisji Rządowej. Efektem przedsięwzięcia były właśnie Opisy zabytków starożytności w Królestwie Polskim, składające się z pięciu tomów tekstu oraz siedmiu atlasów z akwarelowymi wizerunkami monumentów. Ze względu m.in. na niefortunny dla społeczeństwa polskiego obrót dziejów na początku lat 60. XIX w., to monumentalne dzieło nie ujrzało światła dziennego za życia autora (doczekało się publikacji na podstawie czystopisu przechowywanego

${ }^{4}$ K. STRONCZYŃSKI, „Opisy zabytków starożytności przez Delegację wysłaną z polecenia Rady Administracyjnej Królestwa, zebrane w Guberni Lubelskiej w latach 1844 i 1846", Dziennik Powszechny nr 114 (21 maja 1863): 463-464; H. ŁOPACIŃSKI, „Z puścizny naukowej po ś.p. Kazimierzu Stronczyńskim", Wisła 17, z. 3 (1903): 349-352; M. WALICKI, Sprawa inwentaryzacji zabytków $w$ dobie Królestwa Polskiego (1827-1862) (Warszawa: Kasa im. Mianowskiego, 1931).

${ }^{5}$ WaLICKI, Sprawa inwentaryzacji zabytków, 56.

${ }^{6}$ STRONCZYŃSKI, „Opisy zabytków starożytności”, 464.

${ }^{7}$ Por. J.A. WADOwSKI, Kościoly lubelskie na podstawie źródeł archiwalnych (Kraków: Akademia Umiejętności, 1907); I. BuczKowA, Kościót św. Trójcy na Zamku Lubelskim (Lublin: Muzeum Okręgowe w Lublinie, 1983); J. KoZIARSKA-KowALIK, Kaplica Zamkowa w Lublinie (Lublin: Muzeum Lubelskie, 1997); Kaplica Trójcy Świętej na Zamku Lubelskim. Historia, teologia, sztuka, konserwacja. Materialy sesji zorganizowanej w Muzeum Lubelskim 24-26 kwietnia 1997 roku, red. B. Paprocka, J.A. Sil (Lublin: Muzeum Lubelskie, PTTK Oddział w Lublinie, 1999); T. ADAMEK, „Kaplica zamkowa św. Trójcy w Lublinie i jej polichromia”, w Lublin w dziejach i kulturze Polski, red. T. Radzik, A.A. Witusik (Lublin: PTH Oddział w Lublinie, Krajowa Agencja Wydawnicza, 1997), 51-60; A. RÓŻYCKA-BRYZEK, Freski bizantyńsko-ruskie fundacji Jagietly w kaplicy Zamku Lubelskiego (Lublin: Muzeum Lubelskie, Wydawnictwo UMCS, 2000; wyd. 2, red. M. Janik, Lublin: Muzeum Lubelskie, 2012). 
w Gabinecie Rycin Biblioteki Uniwersytetu Warszawskiego dopiero na początku XXI w., dzięki staraniom Jerzego Kowalczyka ${ }^{8}$ ).

Jednak deskrypcja fragmentów malowideł z kaplicy została opublikowana wcześniej niż całość Opisów zabytków Stronczyńskiego. Wraz z serią litografii z widokami guberni lubelskiej ukazała się w 1857 r. w Albumie Lubelskim Adama Lerue'ego' ${ }^{9}$ ucznia warszawskiej Szkoły Sztuk Pięknych i współpracownika Stronczyńskiego podczas terenowych wypraw po guberniach Królestwa Polskiego. Pomijając kwestię wykorzystania przez Lerue'go tekstów autora Opisów oraz akwareli innych artystów, zaangażowanych w akcję inwentaryzacyjną ${ }^{10}$, należy podkreślić zasługę Albumu w upowszechnianiu dzieła Stronczyńskiego, a więc w rozbudzaniu zainteresowań polskimi starożytnościami w szerszym gronie odbiorców niż tylko wąski krąg ówczesnych naukowców. Dzieło Lerue'ego, podobnie jak Opisy zabytków Stronczyńskiego, było wyrazem rosnącego zamiłowania do starożytności ${ }^{11}$. Tę samą tendencję zdradzały inne ówczesne przedsięwzięcia (tj. albumy, wystawy, inicjatywy w zakresie historii sztuki, numizmatyki, sfragistyki), podejmowane przez polskich, zwłaszcza warszawskich, starożytników (np. F.M. Sobieszczańskiego) oraz przez malarzy ze Szkoły Sztuk Pięknych należących do tzw. „Cyganerii malarskiej”, skupionych wokół Marcina Olszyńskiego (np. Wojciech Gerson $^{12}$ ). Atencja dla zabytków była w kręgach polskich elit postawą pokrewną

${ }^{8}$ Kazimierza Stronczyńskiego opisy i widoki zabytków w Królestwie Polskim (1844-1855), t. I: Ogólne Sprawozdanie Delegacji, oprac. J. KowalczYK (Warszawa: Krajowy Ośrodek Badań i Dokumentacji Zabytków, 2009), 7-16, 279-359; t. V: Gubernia Lubelska, oprac. J. Teodorowicz-Czerepińska (Warszawa: Krajowy Ośrodek Badań i Dokumentacji Zabytków, 2014), 185-210; Widoki zabytków Starożytności w Królestwie Polskim stużace do objaśnienia Opisu tychże Starożytności sporządzonego przez Delegację wysłana z polecenia Rady Administracyjnej Królestwa w latach 1852 i 1853 zebrane. Atlas VI. Gubernia Lubelska, Powiat Lubelski (Warszawa, 1855). Por. też D. ZIARKOWSKI, „Inwentaryzacja zabytków Królestwa Polskiego a system ochrony dziedzictwa kulturowego w Rosji w pierwszej połowie XIX wieku”, Sztuka Europy Wschodniej. Искусство Восточной Eвponbl. Art of Eastern Europe 1 (2013): 193-205.

${ }^{9}$ Album Lubelskie. Rysowat z natury $i$ opisat A. Lerue. Poszyt I (Warszawa: A. Pecq et Comp., 1857), 17-18.

${ }^{10}$ Kazimierza Stronczyńskiego opisy, t. I, 7; Kazimierza Stronczyńskiego opisy, t. V, 208-209; zestawienie tekstów Stronczyńskiego z zamieszczonymi przez Lerue'go oraz akwareli z Atlasów z litografiami w Albumie znajduje się w: M. KURZĄTKOwSKI, ,»Album Lubelskie« Adama Lerue'a a »Inwentaryzacja Stronczyńskiego«", Przeglad Lubelski 1 (1965): 147-176; M. KURZĄTKOwSKI, „»Album Lubelskie« Adama Lerue jako źródło ikonograficzne”, w Ikonografia dawnego Lublina, red. Z. Nestorowicz (Lublin, 2000), 52-57.

${ }^{11}$ WaLICKI, Sprawa inwentaryzacji zabytków, 17-31; Kazimierza Stronczyńskiego opisy, t. I, 285-288, 297-299.

${ }^{12}$ Zob. Warszawska „Cyganeria” malarska. Grupa Marcina Olszyńskiego, oprac. S. KoZAKIEWICZ, A. RYSZKIEWICZ (Wrocław: Zakład Narodowy im. Ossolińskich, 1955). 
europejskiej, przede wszystkim francuskiej „antykomanii”. Powstawanie towarzystw archeologicznych, muzeów i podobnych instytucji, sprzyjających budowaniu przekonania o konieczności inwentaryzacji i ochrony spuścizny artystycznej, położyło podwaliny pod gmach narodowej archeologii. Dowartościowanie walorów starożytniczych ,jako siły podtrzymującej ducha jedności narodowej i państwowego twórczego czynnika" ${ }^{13}$ stanowiło ważny etap budzącej się wówczas współczesnej tożsamości narodowej.

\section{U ŹRÓDEŁ ROSYJSKIEJ „ANTYKOMANII” \\ I INWENTARYZACJI POMNIKÓW W KRÓLESTWIE POLSKIM}

W Królestwie Polskim odkrycie i pielęgnowanie starożytności miało dwa oblicza: z jednej strony był to polski, romantyczny passéisme i jednocześnie kult przeszłości jako naukowo-racjonalny oraz społeczno-narodowy obowiązek zachowania pomników ojczystych i przekazania ich przyszłym pokoleniom. Z drugiej zaś carska administracja dokonywała tutaj inwentaryzacji zabytków, co było wyrazem stosunku do pamiątek przeszłości znamiennego dla rosyjskiej XVIII-wiecznej tradycji muzealno-konserwatorskiej, a szczególnie konsekwencją atmosfery okresu kulturowego wrzenia pierwszej ćwierci XIX w. Godny odnotowania jest fakt, że autorem Mowy o pożytku archeologii narodowej $^{14}$, wygłoszonej w Moskwie w 1827 r. przed członkami Towarzystwa Historii i Starożytności i zawierającej ważne rozważania dla rosyjskiej nauki o starożytnościach, był Aleksandr Pisariew, zasłużony w wojnach napoleońskich generał i poeta, doskonale obeznany w sztuce. Był on członkiem Cesarskiej Akademii Rosyjskiej (ośrodka poświęconego nauce o języku i literaturze rosyjskiej, zarodka późniejszego II oddziału Cesarskiej Akademii Nauk w Petersburgu), przyjętym tamże z rekomendacji największego poety oświecenia, Gawriła Dierżawina. Był Pisariew również kuratorem moskiewskiego okręgu szkolnego oraz uniwersytetu (1825-1830), przewodniczącym Moskiewskiego Towarzystwa Historii i Starożytności Rosyjskich (Императорское

${ }^{13}$ WALICKI, Sprawa inwentaryzacji zabytków, 27.

${ }^{14}$ А.А. ПиСАРЕВ, „Речь о пользе отечественной Археологии, произнесенная председателем общества Истории и Древностей российских 21 марта 1827 года”, w Tруды и летописи Общества истории и древностей Российских, учрежденного при Императоском Московском университете, ч. IV, кн. I (Москва: Университетской Тип., 1828), 1-20; por. В.В. Боярченков, „Наука русских древностей в первой половине XIX в.”, w Науки о человеке. История дисииплин, red. А.Н. Дмитриев, И.М. Савельева (Москва: Изд. дом Высшей школы экономики, 2015), 157-186. Por. Kazimierza Stronczyńskiego opisy, t. I, 302-306. 
Московское общество истории и древностей Российских), ale przede wszystkim członkiem Wolnego Stowarzyszenia Miłośników Literatury, Nauk i Sztuk (Вольное общество любителей словесности, наук и художеств, 1804-1826) oraz słynnej Biesiady Miłośników Słowa Rosyjskiego (Беседы любителей русского слова, 1811-1816), stowarzyszenia konserwatywnych intelektualistów - z admirałem A.S. Szyszkowem na czele - zdecydowanie krytycznych wobec liberalnych tendencji z okresu panowania cara Aleksandra I i przeciwnych wpływom cudzoziemskim.

Od 1836 r. Pisariew należał do Rady Administracyjnej Królestwa Polskiego, zaś w 1840 r. objął stanowisko warszawskiego gubernatora wojskowego oraz dyrektora głównego prezydującego w Rządowej Komisji do Spraw Wewnętrznych i Duchownych. Odegrał istotną rolę w podjęciu przez namiestnika I.F. Paskiewicza decyzji o sporządzeniu nowego wykazu zabytków i o powołaniu do tego celu Stronczyńskiego ${ }^{15}$. Był Pisariew człowiekiem oświecenia ${ }^{16}$, konserwatystą, i pomimo pewnej fascynacji tendencjami liberalnymi, jakiej uległ na początku panowania Aleksandra $\mathrm{I}^{17}$, w swoich literackich dziełach, wojskowo-patriotycznych odach i hymnach dał wyraz estetyce klasycyzmu. Tym samym pozostał wierny postulatom obrony „starego

${ }^{15}$ Wedle M. Walickiego Pisariew odgrywał w Królestwie Polskim tę samą rolę, jaka w dobie francuskiej monarchii lipcowej przypadła ministrowi Guizotowi, autorowi ważnego memoriału o inwentaryzacji pomników historycznych. Stronczyńskiego zaś nazwać można by „polskim Vitetem”, w nawiązaniu do francuskiego Generalnego Inspektora pomników historycznych, powołanego na to stanowisko przez Guizota. WALICKI, Sprawa inwentaryzacji zabytków, 21-22, 52. Po Ludovicu Vitet, Generalnym Inspektorem został w 1834 r. dramaturg Prosper Mérimée, którego wkład w ocalenie i odrestaurowanie zabytków starożytności francuskich (rzymskich, celtyckich, średniowiecznych) był ogromny. Oprócz Notatek, sporządzonych podczas podróży po Francji, Mérimée był autorem Studiów nad sztuka średniowieczna, w których przedstawiał swoją wykładnię „gustu narodowego". Przekonywał o ciągłości i utrwalaniu starożytności w dziełach architektury francuskiej, kładąc nacisk na trwały proces naśladowania wzorów antycznych przez francuskich mistrzów średniowiecza. Por. R. DuBbINI, Geografie dello sguardo. Visione e paesaggio in età moderna (Torino: Einaudi, 1994), 127-129; por. tłum. tej pozycji na język angielski: R. DuBBINI, Geography of the Gaze. Urban and Rural Vision in Early Modern Europe (Chicago: University of Chicago Press, 2002).

${ }^{16}$ Wbrew powszechnemu rozumieniu pojęcia „oświecenie”, rosyjskie Просвещңение stawiało owszem naturę w opozycji do „przesądu”, jednak przez spojrzenie wstecz, w nawiązaniu do tradycji narodowej. Pisał Jurij Łotman: «Естественное стало отождествляться с национальным. В русском крестьянине, «мужике» увидели «человека Природы», в русском языке естественный язык, созданный самой Натурой», Ю.М. ЛотмАН, „Архаисты-просветители”, w Из истории русской культуры, т. V (XIX век) (Москва: Издательский дом «ЯСК», 1996), 410-428, tu: 424

${ }^{17}$ Por. ПОэтЫ-РАДИЩЕВЦЫ (А.Х. Востоков, И.П. Пнин, И.М. Борн, В.В. Попугаев и другие поэты Вольного Общества Любителей Словесности, Наук и Художеств), red. П.А. Орлов, Г.А. Лихоткин (Ленинград: Советский писатель, 1979), 376-377; Литературная критика 1800-1820-х годов, red. Л.Г. Фризман (Москва: Худож. лит., 1980), 48-55. 
stylu” (старый слог), jakie formułowali „archaiści” na czele z Szyszkowem i Dierżawinem, przeciwstawiający się „,nowatorom” (zwolennikom modernizacji języka rosyjskiego pod dewizą élegance, tj. stylu „francuskiego”), skupionym w towarzystwie literackim „Arzamas” ${ }^{18}$ wokół programu estetycznego N.M. Karamzina. Niemniej diametralne różnice w poglądach Szyszkowa i Karamzina na temat kwestii literacko-językowych oraz wizji historycznej ${ }^{19} \mathrm{z}$ czasem zacierały się. Względna ,zgodność” ich zapatrywań ujawniła się po zawarciu między Aleksandrem I a Napoleonem porozumienia w Tylży w 1807 r., zdaniem wielu Rosjan poniżającego. W 1810 r. Karamzin opublikował traktat Записка о древней и новой России, zgadzając się co do konieczności obrony rosyjskiej autokracji przed reformami Aleksandra I.

Wizja historii i kultury zawarta w Mowie o pożytku archeologii narodowej Pisariewa była swego rodzaju syntezą myśli Szyszkowa i Karamzina. Jego koncepcja nawiązywała wprost do wzorców etatyzmu (historia jako „obowiązek czynu i służba państwowa" ${ }^{20}$ ) zaprezentowanych w słynnej karamzinowskiej Истории государства российского oraz do dzieła Опыты истории, письмен и нравоучения M.N. Murawiowa, poety cieszącego się uznaniem w bractwie Arzamas, który notabene piastował również stanowisko kuratora moskiewskiego okręgu szkolnego i uniwersytetu. Powołując się na Murawiowa, Pisariew przekonywał o konieczności poznawania historii ojczystej nie tylko w tradycyjny sposób - poprzez historię pisaną, lecz także z pomocą zabytków archeologicznych, dzieł literatury pięknej, monet, medali, tradycji oralnej. Poszanowanie i odwoływanie się do pomników przeszłości było zresztą postawą wspólną wielu intelektualistom, „szermierzom stariny” (ревнителей

${ }^{18}$ A. WALICKI, Zarys myśli rosyjskiej. Od Oświecenia do Renesansu religijno-filozoficznego (Kraków: Wydawnictwo Uniwersytetu Jagiellońskiego, 2005), 97-99, 103-109. Przypomnijmy niektóre słynne nazwiska członków Arzamasu: S.S. Uwarow, D.N. Błudow, W.A. Żukowskij, P.A. Wiazemskij, K.N. Batiuszkow, A.S. Puszkin. Zob. także M. АльтшуллЕР, Беседа любителей русского слова: У истоков русского славянофильства (Москва: Новое литературное обозрение, 2007); М. МАЙофис, Воззвание к Европе: Литературное общество «Арзамас» и российский модернизационный проект 1815-1818 годов (Москва: Новое Литературное Обозрение, 2008).

${ }^{19}$ Pierwszy postulował powrót do wyimaginowanego status ante quo, drugi miał wizję postępową, dlatego Mark Altszuller uznał Karamzina ante litteram za „zapadnika”, Szyszkowa za „,\$łowianofila”. Zob. АльтшуллЕР, Беседа любителей русского слова, 47-48. O Szyszkowie jako o prekursorze słowianofilstwa w mniemaniu samych słowianofilów, od Sergiusza Aksakowa do Aleksieja Chomiakowa, zob. A. WALICKI, $W$ kregu konserwatywnej utopii. Struktura i przemiany rosyjskiego stowianofilstwa (Warszawa: Wydawnictwo Naukowe PWN, 2002), 175, 177.

${ }^{20}$ G. GIRAUDO, „La traduzione veneziana della Istorija gosudarstva rossijskogo (note bibliografiche e lessicografiche)", w Profili di Storia veneta. Sec. XVIII-XX, red. U. Corsini (Venezia: Università degli Studi - Ca' Foscari, 1985), 95-128, tu: 108. Por. też G. GIRAUDO, „Bayer et Tatiščev: l'histoire comme érudition ou comme service de l'Etat', Europa Orientalis 5 (1986): 351-371. 
старины) zarówno w obozie tradycjonalistów, na czele z Sziszkowem, jak i w środowisku reformatorów (S.S. Uwarow) ${ }^{21}$. Za Murawiowem Pisariew powtarzał, że „nie ma nic bardziej godziwego dla obywatela niż zaciekawienie sławnymi wydarzeniami, starożytnościami, dziejami i obyczajami Ojczyzny. Nieznajomość owych osobliwości narodowych jest równoznaczna z byciem cudzoziemcem!"22.

Mowa Pisariewa, utrzymana we wzniosłym stylu, była pochwałą Rosji jako kolebki wdzięku, moralności i sztuki oraz wyrazem głębokiego uznania dla uczonych „ludzi oświeconych” (мужей просвещенных), miłośników starożytności, którzy zapoczątkowali odkrycie stariny w świadomości społeczeństwa rosyjskiego. Zadanie członków Towarzystwa Historii i Starożytności miało więc polegać na „pokazaniu współczesnym sławy i wielkości Przodków naszych [...]. W ten sposób ożywione zostaną dawne czasy, by mogły rywalizować z teraźniejszością i przyszłością!”23, a takie przedsięwzięcie wzbudzi dla odkrywców stariny głęboką wdzięczność u potomnych. Pisariew tworzył w latach ponapoleońskich, gdy przez Rosję przechodziła fala patriotyzmu i dumy narodowej, zaś w społeczeństwie utrwalało się przekonanie o rosnącym znaczeniu imperium rosyjskiego na arenie międzynarodowej. Innymi ważnymi wydarzeniami, które determinowały wówczas polityczny i społeczny zwrot ku ideologii imperialnej, były powstanie dekabrystów, początek panowania Mikołaja I oraz powstanie listopadowe. W wypowiedzi Pisariewa słychać karamzinowskie rozumienie racji stanu i jedności imperium, w skład którego miały wchodzić terytoria dziedzicznie przynależące do domu Romanowów (gubernie zachodnie) oraz obszary takie jak Królestwo Polskie, które gwarantowałyby jedność imperium na płaszczyźnie czystej Realpolitik.

\footnotetext{
${ }^{21}$ Postawa ta, wyrażająca dążenie do odzyskania utraconej więzi z przeszłością i tradycją, zdaniem Gianfranca Giraudo była swego rodzaju spiritus movens historii Rosji: „Kult stariny [...] wraz z obsesją na punkcie sakralnej jedności Rusi jest jednym z fundamentów politycznej myśli czasów Księstwa Moskiewskiego, a także politycznej myśli rosyjskiej w ogóle aż do czasów sowieckich. Każda reforma zmierzać winna do odzyskania utraconej jedności гр'kхz радн нашнхz (jedności utraconej z powodu odejścia od tradycji ze strony jakiegokolwiek władcy), integralności, którą może zapewnić tylko wierność ideowo czystej, pierwotnej starinie, tak zobowiązującej, jak niewysławialnej”, G. GIRAUDO, „L’Ucraina e gli Ucraini dal passato al futuro”, Studi Slavistici 1 (2004): 25-33, tu cytat ze strony 31 .

22 «нет ничего приличнее гражданину, как любопытное внимание к славным произшествиям, к древностям, к местным обстоятельствам и обыкновениям своего Отечества. Не знать сих особенностей народных - есть тоже, что быть иностранцем!...», ПиСАРЕВ, „Речь о пользе отечественной Археологии", 2.

${ }^{23}$ ПиСАРЕВ, „Речь о пользе отечественной Археологии”, 7.
} 
Wyraźne są też u Pisariewa zarodki nowoczesnej myśli narodowej w postaci „oficjalnego nacjonalizmu”, doktryny, w której dworiaństwo zaczynało być traktowane jako podstawowy nośnik rosyjskości (русскости), со wchodziło w konflikt z tradycyjną rolą elit nierosyjskich w wielonarodowym imperium $^{24}$. W oficjalnej narracji brakowało jeszcze wówczas odniesień do idei $l u d u$ rosyjskiego jako czynnika narodowotwórczego; znajdzie ona swój wyraz w poglądach części wykształconego społeczeństwa rosyjskiego dopiero w latach po powstaniu styczniowym ${ }^{25}$. Koncepcja „oficjalnego nacjonalizmu”, uwieczniona w słynnym okólniku ministra Siergieja Uwarowa z 1833 r. i od lat 80. XIX w. nazywana teorią „oficjalnej narodowości” ${ }^{26}$, za filary państwa uznawała narodowość i prawosławie w ramach samodzierżawia. W tej słynnej triadzie Uwarowa pojęcia narodowości i prawosławia miały wydźwięk czysto świecki ${ }^{27}$ (pełniły one w istocie rolę narzędzi władzy, były więc funkcjonalne dla ideologii państwa, które miało kształtować swoją tożsamość w warunkach zbliżenia do Europy). Pisariew natomiast, podążając za Szyszkowem, podstawową rolę $\mathrm{w}$ kształtowaniu tożsamości rosyjskiej przypisywał językowi rosyjskiemu jako spadkobiercy języka staro-cerkiewno-słowiańskiego ${ }^{28}$

${ }^{24}$ Zob. klasyczną pozycję: A. KAPPELER, Rußland als Vielvölkerreich. Entstehung, Geschichte, Zerfall (München: C.H. Beck), 1992.

${ }^{25}$ H. GŁĘBOCKI, Fatalna Sprawa. Kwestia polska w rosyjskiej myśli politycznej (1856-1866) (Kraków: Arcana, 2000); H. Głębocki, „Irredenta polska a kresy Imperium. Powstanie Styczniowe (1863-1864) a ewolucja polityki Imperium Rosyjskiego wobec jego zachodnich »okrain«”, w idem, Kresy Imperium. Szkice i materiaty do dziejów polityki Rosji wobec jej peryferii (XVIII-XXI) (Kraków: Arcana, 2006), 306-363.

${ }^{26}$ Wprowadzona nazwa „oficjalna narodowość” została nadana teorii uwarowowskiej przez krytyka literackiego Aleksandra N. Pypina w 1873 r., kiedy ukazało się jego studium Xapaктеристики литературных мнений от двадиатых до пятидесятых годов (Санкт Петербург: ТиП. М.М. СТАСЮЛЕВИЧА, 1873), zwłaszcza rozdział II: Народность официальная, 61-110.

${ }^{27}$ А. ЗОРин, „Заветная Триада. Меморандум С.С. УВАРОВА 1832 года и возникновение доктрины „православие - самодержавие - народность”, w idem, Кормя двуглавого орла... Литература и государственная идеология в России в последней трети XVIII-первой трети XIX века (Москва: Новое литературное обозрение, 2004), 337-374. Por. Т. Симосато, Переосмысление концепщии «народность»: С.С. Уваров как консервативный мыслитель, Мысль 20 (2016): 87-97. A. Miller, „'Official Nationality’?: A Reassesment of Count Sergei Uvarov's Triad in the Context of Nationalism Politics", w idem, Romanov Empire and Nationalism: Essays in the Methodology of Historical Research (Budapest-New York: Central European University Press, 2008), 139-160.

${ }^{28}$ ПиСАРЕВ, „Речь о пользе отечественной Археологии”, 16-17. O przekonaniu na temat wiodącej roli języka rosyjskiego w nauce, zwłaszcza w geografii i starożytnictwie rosyjskim świadczy chociażby przewaga, od około połowy XIX w., frakcji rosyjskiej nad frakcją niemiecką w Cesarskim Towarzystwie Geograficznym (zasługa etnografa N.I. Nadieżdina) oraz w Towarzystwie Archeologicznym (inicjatywa I.P. Sacharowa). Por. Д.Н. Анучин, О задачах русской этнографии (Несколько справок и общих замечаний), кн. I (Москва: «Русская» типо-лит., 
oraz tradycyjnym wartościom wyimaginowanej „symfonii” tronu i ołtarza (rzecz jasna w epoce, gdy ołtarz był całkowicie podporządkowany tronowi) ${ }^{29}$.

Apoteoza wielkości Imperium rosyjskiego wybrzmiewa także w lirycznej prozie Pisariewa, w której tworzy on poemat ku chwale Rosji niczym XVIII-wieczną odę panegiryczną. Podkreśla niezwykłą różnorodność i wielkość geograficzną państwa carów ${ }^{30}$, eksponując rolę zachodnich terenów, czyli dawnych wschodnich obszarów Rzeczypospolitej czy np. krzyżackiej Liwonii: „Na zachodzie włożymy miecz do pochwy i obejmiemy życzliwie Polaka i Niemca!" 31 . Niemal idylliczny obraz zostaje zwieńczony plastyczną ilustracją cesarskiego „pozytywnego panowania” (положительное владычество): „Jednym słowem, wyważymy zarówno bułatny miecz wojownego Swiatosława, jak i złote berło mądrego Włodzimierza"32. Słowa te zgodne są z ideologią, jaką kierowali się władcy rosyjscy, uprawiając politykę imperialną. W podobnym duchu wypowiadał się np. Aleksander II na początku swojego panowania, podczas wizyty w Warszawie wygłaszając słynne słowa: „Point de rêveries, messieurs! Szczęście Polski leży w całkowitym jej połączeniu z narodami mojego imperium. To, co uczynił mój ojciec, zrobił dobrze, i ja to

1889), 6-19; Н. НАЙт, „Наука, империя и народность: Этнография в Русском географическом обществе, 1845-1855", w Российская империя в зарубежной историографии. Работы последних лет: Антология, red. П. Верт, П.С. Кабытов, А.И. Миллер (Москва: Новое изд-во, 2005), 155-198; В.В. БоярчЕнков, „Наука русских древностей”, 178-179. O istotnej różnicy między ideologią Szyszkowa a koncepcją Uwarowa zob. Зорин, „Заветная Триада”, 366-367. Ciągłość myślową między nimi stwierdzono natomiast w J. KuCHARZEwsKi, Epoka Paskiewiczowska. Losy oświaty (Warszawa-Kraków: Gebethner \& Wolff, 1914), 14.

${ }^{29} \mathrm{Na}$ ten temat zob. Ю.М. ЛотмАН, „Архаисты-просветители”. Staroruskie zabytki cerkiewne jako część składową spuścizny państwa rosyjskiego postrzegał A.A. ПисAРЕВ, „Киевские древние памятники”, w Записки и труды Общества истории и древностей Российских, учрежденного при Императоском Московском университете, ч. II (Москва: Унив. тип., 1824), 144-166.

30 «Сдружимся, так сказать, теснее с Отечеством своим, не станем издали дивиться свойству наших предков, пренебрегать своею страною разнообразною и обильною!», Писарев, „Речь о пользе отечественной Археологии”, 7. Por. rozważania Pisariewa o „Kraju noworosyjskim" jako o nieodłącznej części imperium a więc o wpisaniu go w poczet historii i starożytności rosyjskich: A.А. ПиСАРЕВ, „О древностях Новороссийского края”, w Труды и летописи Общества истории и древностей Российских, учрежденного при Императоском Московском университете, ч. V, кн. I (Москва: Университетской Тип., 1830), 192-214. O „geороеtусе” i „mapowaniu” imperium, wedle trafnych określeń Andrzeja Nowaka, w dziełach najważniejszych literatów Rosji carskiej, m.in. Łomonosowa i Dierżawina zob. A. NowAK, „Pod kopytami Miedzianego Jeźdźca - „geopoetyka” rosyjska i Polska”, w idem, Metamorfozy Imperium Rosyjskiego 1721-1921. Geopolityka, ody i narody (Kraków: Wydawnictwo Literackie, 2018), 19-74.

31 «На Западе же вложим мечь свой во влагалище, и обымем дружелюбно Ляха и Тевтона!», Писарев, „Речь о пользе отечественной Археологии”, 8.

32 «Словом, взвесим и булатный мечь бранного Святослава и златый скипетр мудрого Владимира», Писарев, „Речь о пользе отечественной Археологии”, 8. 
będę utrzymywać"33. Pomimo uzasadnionych nadziei Polaków na złagodzenie polityki imperialnej i faktycznej odwilży, która nastąpiła po 1855 r., mowa imperatora stanowiła symbol ciągłości między jego epoką a poprzednią, mikołajowską, w której Królestwo Polskie miało zlać się z cesarstwem rosyjskim.

W takim oto kontekście narodził się więc projekt opisu pomników starożytności - w ramach zbliżenia Królestwa z carskimi instytucjami („rusyfikacja administracyjna"). Przedsięwzięcie dotyczące zabytków sztuki stanowiło kolejny krok w procesie poznawania przez urzędników carskich przestrzeni imperium. Stopniowo nabierał kształtu obraz „malowniczej Rosji”, w następnych dziesięcioleciach znajdujący odbicie w kolejnych wydawnictwach, które - idąc za przykładem podobnych publikacji europejskich ${ }^{34}$

33 «Point de rêveries, messieurs! Счастье Польши заключается в полном слитии ее с народами моей империи. То, что мой отец сделал, хорошо сделано, и я поддержу это», А.А. Сидоров, Русские и русская жизнь в Варшаве (1815-1895) (Варшава: Тип. Губ. правл., 1899), 120-121.

${ }^{34}$ Pośród wydawnictw rosyjskich zob. np. И.М. СНЕГИРеВ, Памятники Московской древности, с присовокуплением очерка монументальной истории Москвы и древних видов и планов древней столиць (Москва: тип. А. Семена, 1842-1845); И.М. СНЕГИРЕВ, Русская старина в памятниках иерковного и гражданского зодчества (Москва: В Полицейской тип., 1848-1860); Живописная Россия. Отечество наше в его земельном, историческом, племенном, экономическом и бытовом значении, red. П.П. Семенова, t. I-XII (С.-Петербург-Москва: Изд. М.О. Вольф, 1881-1901); Памятники русской старины в западных губерниях, издаваемые с высочайшего соизволения red. П.Н. Батюшков, вып. I-VIII (С.-Петербург: Издание Министерства Внутренних Дел, 1868-1885). Na szczególną uwagę zasługuje album rysunków malarza, absolwenta słynnej uczelni im. Stroganowa w Moskwie i znawcy moskiewskiej prawosławnej stariny Dmitrija Strukowa. $\mathrm{Z}$ ramienia Cesarskiego Towarzystwa Archeologicznego i inicjatywy m.in. slawisty I.I. Sriezniewskiego, Strukow przeprowadził ekspedycję naukowo-badawczą po krajupółnocno-zachodnim w celu inwentaryzowania zabytków przeszłości. Album doczekał się pierwszego wydania dopiero w $2011 \mathrm{r}$ : Д. Струков, Альбом рисунков. 1864-1867, red. О. Д. Баженова (Минск: БелЭн, 2011). O poznawaniu terytorium azjatyckiej części Rosji zob. A. MASOERO, „Linee di frattura nell’Impero zarista. Uno sguardo d'insieme”, Storica 17, nr 50 (2011): 34-35. Źródła inspiracji dla popularyzowania malowniczych (picturesque) widoków kraju można odnaleźć w albumach pejzażowych (Voyages pittoresques et historiques), które od XVIII w. (wieku wedutystów) stały się modne w Europie. W następnym stuleciu oświeceniową ciekawość świata i wyidealizowane przedstawienie przyrody uzupełnił imperatyw patriotyczno-dydaktyczny, co umożliwiło rozpowszechnianie podobnych przedsięwzięć wydawniczych. O „malowniczości antykwarycznej” pisał Renzo Dubbini, który obserwował, jak ową malowniczość „stosowano w celu uporządkowania, przedstawienia i rekonstrukcji obrazu znaczącego dziedzictwa narodowego [podkr. M.P.]", por. DuBBINI, Geografie dello sguardo, szczególnie rozdz. III: Visioni della natura e dell'antico, 66-89 oraz V: Il viaggio pittoresco, 109-139, tu: 125. Dubbini wskazuje ponadto na litografie jako na ważne narzędzie artystów romantyzmu, służące rozpowszechnianiu świadomości narodowej: „Dzięki lekkości znaku i cieniowanych kontrastów litografia zdaje się być idealnym środkiem dla utrwalenia wolnych wrażeń podróżnika. Gdy grawerowanie odpowiada głównie wymaganiom dokładności opisu, litografia bardziej przystaje do wyrażania emocjonalnego charakteru weduty. [...] spojrzenie archeologa ponoć nie ogranicza się do poznania zabytku, chce zaś, by ten odżył poprzez jego przedstawienie", DuBBINI, Geografie dello sguardo, 126-127. We Francji zostały wydane np. Nouveau voyage pittoresque de la France (Paris: Ostervald l'aîné, 1817); Voyages pittoresque et romantiques dans l'Ancienne France, red. Ch. Nodier, I. Taylor, A. de Cailleux 
miały na celu kulturowe przyswojenie szerokiemu gronu odbiorców skrajnie różnorodnej przestrzeni imperium. W Królestwie Polskim opracowanie dzieł architektury i sztuki przeprowadzono w czasie, kiedy między władzą rosyjską a przedstawicielami polskiej elity była możliwa faktyczna współpraca. Dowodem tego jest rzetelna kooperacja urzędników carskich ze Stronczyńskim, szczególnie wyraźna w przypadku M.I. Pawliszczewa, radcy stanu, historyka ${ }^{35}$, od 1831 r. w służbie w Królestwie Polskim. Pawliszczew był ważną postacią w Heroldii Królestwa Polskiego, gdzie blisko współpracował ze Stronczyńskim nad Herbarzem rodzin szlacheckich Królestwa Polskiego (1853). Podczas pracy terenowej w ramach drugiego etapu inwentaryzacji (1851-1853), Stronczyński zgłosił Komisji Rządowej zalecenie powierzenia właśnie Pawliszczewowi, „osobie z historią i starożytnościami Rosyjskimi więcej obeznanej”, pracy we wschodnich obszarach guberni lubelskiej mających przewagę ludności ruskiej. Sugestia polskiego badacza nie została jednak przyjęta przez Komisję $e^{36}$. Nad kryteriami pochodzenia etnicznego czy wyznania przeważyły bowiem względy organizacyjne i merytoryczne, podyktowane obawą, że podział pracy pomiędzy dwóch inwentaryzatorów wpłynie negatywnie na jednolitość dzieła. Tego typu stosunek władzy rosyjskiej do kwestii wyłonienia najlepszego inwentaryzatora jest kolejnym argumentem na rzecz konkluzji, że ówczesną wizję państwa urzędników carskich można ująć w kategoriach narracji ,imperialnej”. Natomiast zwrot w kierunku narracji nacjonalistycznej, odwołującej się do koncepcji etniczno-wyznaniowej i rosyjskocentrycznej,

(Paris: P. Didot l'ainé, etc., 1820-1878); A. Hugo, France pittoresque ou description pittoresque, topographique et statistique des départements et colonies de la France (Paris: Delloye, 1835). W ramach imperium austro-węgierskiego i pod patronatem arcyksięcia austriackiego Rudolfa ukazało się ważne dzieło, tzw. Kronprinzenwerk: Die österreichisch-ungarische Monarchie in Wort und Bild (Wien: Verlag der Kaiserlich-Königlichen Hof- und Staatsdruckerei, 1886-1902), pod red. J. Weila von Weilen dla wydania niemiecko-języcznego oraz M. JÓKAIA dla wydania w języku węgierskim. Polskie przedsięwzięcia godne uwagi to m.in.: J.K. WILCZYŃsKI, Album wileńskie (Paryż, 1842-1875); Teka Michała Kuleszy: zbiór widoków krajowych rysowanych z natury, Poszyt pierwszy (Paryż: Imprimerie Lemercier, 1852), oraz monumentalne dzieło Napoleona Ordy: Album Widoków Historycznych Polski poświęcony Rodakom zrysowany z natury przez Napoleona Ordę (Warszawa: Gebethner \& Wolff, 1873-1883). Por. Y. LISAI, „Pejzaże Napoleona Ordy - Narodowy koloryt międzynarodowej weduty”, w Napoleon Orda (1807-1883): ilustrowana encyklopedia kraju. Wystawa z kolekcji Muzeum Narodowego w Krakowie w Narodowym Muzeum Sztuki Republiki Białorusi (Kraków: Muzeum Narodowe w Krakowie, 2017), 15-19; A. FEDORUK, „Ukraina oczami Napoleona Ordy”, w Napoleon Orda 1807-1883. Materiaty międzynarodowej konferencji naukowej poświęconej 200. rocznicy urodzin artysty (Brześć: Konsulat Generalny RP w Brześciu, 2007), 23-30.

${ }^{35}$ Profesor w gimnazjum warszawskim, autor historii Polski Польская история в виде учебника (Варшава: В казенной типографии, 1843), w której uzasadniał rozbiory Rzeczypospolitej anarchią państwową w niej panującą.

${ }^{36}$ WALICKI, Sprawa inwentaryzacji zabytków, 63-65. 
dokonał się po powstaniu styczniowym. To wtedy zniesiono ostatecznie autonomię Królestwa Polskiego, przekształcając je w 1874 r. w generalne gubernatorstwo warszawskie, składające się $\mathrm{z}$ dziesięciu guberni bezpośrednio podporządkowanych petersburskich władzom.

\section{GRANICE NACJONALIZMU ROSYJSKIEGO A STAROŻYTNOŚCI PO POWSTANIU STYCZNIOWYM}

Kolejne etapy odkrywania ściennych malowideł w kaplicy Świętej Trójcy na Zamku Lubelskim miały miejsce w latach popowstaniowych, a dokładniej na przełomie XIX i XX w., w głęboko zmienionej sytuacji politycznej. Rosyjscy historycy i publicyści pochodzenie lubelskich fresków zinterpretowali jednoznacznie, uznając je za dzieła przynależne do dziedzictwa sztuki rosyjskiej, nie zaś polskiej ${ }^{37}$. Tego rodzaju interpretacje należy odczytywać w świetle ówczesnej narracji polityczno-ideologicznej, nierozerwalnie połączonej $\mathrm{z}$ kontekstem geograficznym. Kategorią szczególnie przydatną $\mathrm{w}$ trakcie analizy powiązania pomiędzy „oswajaniem” przestrzeni a polityką nacjonalistyczną jest pojęcie map mentalnych, opisujące geografię w służbie nacjonalizmu. Mapy mentalne, które nie są modelem dla przedstawienia rzeczywistości, lecz instrumentem rzutowania wyobrażeń na rzeczywistość ${ }^{38}$, bywają narzędziem „naukowego" potwierdzania wyobrażonych wspólnot; taką też rolę „mapowanie" odgrywało w rosyjskim dyskursie nacjonalistycznym.

Historia odkrycia bizantyjskich malowideł z lubelskiej kaplicy stanowi doskonały materiał dla analizy realnych i wyobrażonych granic rosyjskiego nacjonalizmu oraz do rozważenia, jakie miejsce w geografii wyobrażonej, na „mentalnej mapie" zajmował Lublin. Będę próbował odpowiedzieć na pytania o to, czy Lublin mógł zostać zaliczony do obszaru wschodniej Słowiańszczyzny

${ }^{37} \mathrm{O}$ sztuce jako narzędziu rosyjskiej narracji imperialnej zob. P. PASZKIEWICZ, $W$ stużbie Imperium Rosyjskiego, 1721-1917. Funkcje i treści ideowe rosyjskiej architektury sakralnej na zachodnich rubiezach cesarstwa i poza jego granicami (Warszawa: Instytut Sztuki PAN, 1999).

${ }^{38}$ B. ANDERSON, Wspólnoty wyobrażone. Rozważania o źródtach i rozprzestrzenianiu się nacjonalizmu, przekł. S. Amsterdamski (Kraków: Społeczny Instytut Wydawniczy, 1997), 169-170 (szczególnie rozdział Spis, mapa, mиzеum, 159-181). Por. też А. МиллеР, Империя Романовых и начионализм. Эссе по методологии исторического исследования (Москва: Новое литературное обозрение, 2006), zwłaszcza rozdział Империя и нация в воображении русского национализма, 147-170; А.И. Миллер, „Тема Центральной Европы: история, современные дискурсы и место в них России”, Новое литературное обозрение 52, nr 6 (2001): 75-96; Ф.Б. Шенк, „Ментальные карты: конструирование географического пространства в Европе от эпохи Просвещения до наших дней”, Новое литературное обозрение 52, nr 6 (2001): 42-61. 
(ziem ruskich, które w rozumieniu rosyjskich nacjonalistów były utożsamiane tout court ze światem rosyjskim) oraz czy według ideologii rosyjskiego nacjonalizmu Lublin przynależał do ziem rdzennie rosyjskich, czy też samo miasto i Lubelszczyzna miały zostać objęte zabiegami „,powrotu” do rosyjskości i prawosławia, podobnie jak sąsiednia Chełmszczyzna. Ta ostatnia, w okresie przynajmniej na 30 lat przed odkryciem fresków w Lublinie, stanowiła obiekt dążeń rusyfikacyjnych carskiej władzy, których przejawem była działalność miejscowych gorliwych czynowników, zarówno przedstawicieli biurokracji carskiej, jak i urzędników cerkiewnych. Rusyfikację czy depolonizację uzasadniano obecnością na tych terenach Rusinów należących do kościoła greckokatolickiego. Jak wiadomo, unici byli historycznie dawnymi prawosławnymi, oderwanymi od Cerkwi wschodniej za sprawą unii brzeskiej. W rozumieniu nacjonalistów rosyjskich powinni byli zatem powrócić do macierzystej Cerkwi, co równocześnie oznaczało ich powrót do rosyjskości.

W perspektywie nacjonalistów świat rosyjski i prawosławny sięgał do terenów zamieszkałych przez unitów, których uznano za prawosławnych w 1875 r. po kasacie chełmskiej diecezji greckokatolickiej (obejmującej Chełmszczyznę i Podlasie $)^{39}$. Ich „nawrócenie” było określane jako „powrót do wiary ojców". Rosyjscy nacjonaliści przekonywali bowiem, że ziemie zamieszkane przez dawnych unitów (określane jako „Ruś Chełmska”) należały niegdyś nie tylko do państwa ruskiego (więź dynastyczna), lecz również do świata kultury rosyjskiej i prawosławia (więź ducha i krwi). Ludność ruska zamieszkująca te tereny uznawana była za rdzennie rosyjską (исконно русская земля, вотчина księcia halickiego Daniela Romanowicza), część „wielkiego narodu rosyjskiego" (Большой русской нации) ${ }^{40}$. Mało- i BiałoRusini mieli się zbliżyć do głównego wielkorosyjskiego trzonu, zachowując pewne odmiany lokalne; przypomnijmy np. próby wprowadzenia elementów języka ukraińskiego (малорусский) zarówno do paraliturgii, jak i do szkół.

${ }^{39}$ O kasacie Kościoła greckokatolickiego w Królestwie Polskim zob. np. Th.R. WEEKS, „The „End" of the Uniate Church in Russia: The Vossoedinenie of 1875”, Jahrbücher für Geschichte Osteuropas 44, H. 1 (1996): 28-40.

${ }^{40} \mathrm{O}$ роје̨сіu „большая русская начия” zob. А. МиллЕР, «Украинский вопрос» в политике властей и русском общественном мнении (вторая половина ХІХ в.) (С.-Петербург: «Алетейя», 2000), 31-41; Л.Е. ГоРизонтов, „«Большая русская нация» в имперской и региональной стратегии самодержавия", w Пространство власти: исторический опыт России и вызовы современности, red. Б.В. Ананич, С.И. Барзилов (Москва: Московский общественный научный фонд, 2001), 129-150. Por. też Западные окраины Российской империи, red. М.Д. Долбилов, А.И. Миллер (Москва: Новое литературное обозрение, 2006); М.Д. Дольилов, Русский край, чужая вера: Этноконфессиональная политика империи в Литве и Белоруссии при Александре II (Москва: Новое литературное обозрение, 2010). 
Politykę władzy carskiej wobec wschodnich obszarów Kongresówki należy więc odróżnić od polityki stosowanej względem innych części Królestwa. W pierwszym przypadku należałoby mówić o „unarodowieniu”41 ludności z terenów byłej diecezji chełmskiej. Królestwo Polskie kojarzono zwykle z ludnością etnicznie polską, wyraźnie odmienną od zamieszkałej na terytoriach wschodniosłowiańskich ${ }^{42}$. Po powstaniu styczniowym, które okazało się katalizatorem rosyjskich uczuć narodowych (sprzyjał im także szybki rozwój nauk etnograficznych i językoznawczych) oraz „odkryciu” ludności ruskiej w granicach Kongresówki ${ }^{43}$, władze rosyjskie doszły do wniosku, że na ziemiach wschodnich Królestwa Polskiego należy przywrócić „sprawiedliwość historyczną”, a więc „zasadę rosyjską i prawosławną”. Nieco inaczej sytuacja przedstawiała się w pozostałych guberniach Królestwa. Tutaj, mimo wyraźnej niechęci do kultury polskiej, decyzję o wprowadzeniu rosyjskiego jako języka urzędowego czy języka szkolnictwa należy postrzegać w kontekście polityki imperialnej, którą można by nazwać rusyfikacją administracyjną (nie zaś „narodową”). Miała ona co prawda również wymiar kulturowy

${ }^{41} \mathrm{Na}$ temat unarodowienia por. E. WeBer, Peasants into Frenchmen. The Modernization of Rural France, 1870-1914 (Stanford: Stanford University Press, 1976); M. LuCZEWSKI, Odwieczny naród. Polak i katolik w Żmiącej (Toruń: Wydawnictwo Naukowe UMK, 2012); D. STALIŪNAS, „Assimilation or Acculturation? Russian Imperial Policy Toward Lithuanians in the 1860s", Central and Eastern European Review 2 (2008): 1-20; w sprawie unarodowienia ludności ruskiej na Chełmszczyźnie zob. M.M. PRZECISZEwSKA, „»Tworzenie Rosjan«. Narodowotwórcza funkcja wybranych publikacji Bractwa Przenajświętszej Bogurodzicy w Chełmie (1884-1915)”, Rocznik Biblioteki Narodowej 48 (2017): 347-372.

${ }^{42}$ Por. D. Staliūnas, Making Russians. Meaning and Practice of Russification in Lithuania and Belarus after 1863 (Amsterdam-New York: Rodopi, 2007), 12-13; МиллеР, Империя Романовых и национализм, 149-150.

${ }^{43}$ Poświadczają to teksty rosyjskich autorów dowodzące, iż przed powstaniem styczniowym carat nawet nie podejrzewał istnienia w Królestwie Polskim ludności ruskiej, która - choć różniła się zdecydowanie od polskiej - została od Polaków uzależniona, spolonizowana i częściowo nawrócona na katolicyzm. Por. np. И.И. СонЕвицкий, Холмщина. Очерки прошлого (С.-Петербург: Тип. А.С. Суворина, 1912), 7-8. Zdaje się, że „odkrywcą” Rusinów chełmskich jeszcze w 1861 r. był wpływowy, cieszący się uznaniem rosyjskiej opinii publicznej historyk Michaił Pogodin. Pierwsza wzmianka o Białorusinach i Małorusinach wschodniej części Królestwa Polskiego znajduje się w artykule Posłanije k Polakam autorstwa rosyjskiego historyka. Głosił on potrzebę przyłączenia terenów wschodnich Królestwa do guberni zachodnich aby obronić je przed stopniową polonizacją Małorusinów i Białorusinów z Augustowa i guberni lubelskiej (Chełmszczyzny). М.П. Погодин, Послание к Полякам (1861), w idem, Польский вопрос. Собрание рассуждений, записок и замечаний, 1831-1867 (Москва: В типографіи газеты «Русскій» 1868), 69, 74. Por. M. PICCIN, „Geografie wyobrażone rosyjskiego nacjonalizmu: gubernie zachodnie Imperium i „Ruś Chełmska” między tradycją a nowoczesnością myśli narodowej”, w Przypominać zapomniane, odkrywać nieznane. Polskie losy: Kościót - Syberia - Rosja (XIX-XX w.). Studia ofiarowane Profesorowi Eugeniuszowi Niebelskiemu w 70. rocznicę urodzin, red. A. Barańska (Lublin: Towarzystwo Naukowe KUL, 2019), 205-224. 
i cywilizacyjny ${ }^{44}$, jednak carowie oraz większość wyższych urzędników rosyjskich byli świadomi, że kultury polskiej nie da się zrusyfikować ${ }^{45}$.

Lublin, choć był miastem położonym tuż przy pograniczu polsko-ruskim, należał do kultury polskiej. Nie planowano wobec miasta rusyfikacji narodowej; nie sposób znaleźć w źródłach XIX-wiecznych świadectw pretensji do jego rosyjskości. W corocznej publikacji urzędowej guberni lubelskiej Памятная Книжка, z 1903 r., czy w słowniku encyklopedycznym Brockhauz-Efron Lublin jest przedstawiany jako miasto polskie, które tylko w połowie XIII w., w czasach krótkiego panowania na tym terenie ruskiego księcia Daniela Romanowicza $^{46}$, stanowiło przedmiot sporu, niedonoszącego się do kwestii narodowej, między Polską a ruskimi książętami (których skądinąd w rosyjskiej retoryce nacjonalistycznej utożsamiano z Rosjanami). Taka odległa przeszłość nie była wystarczającym argumentem, aby uznać Lublin za miasto rosyjskie. Odsłonięcie bizantyjskich fresków w Lublinie, mieście sąsiadującym z ziemią chełmską, mogło więc spowodować zasadniczą rewizję map mentalnych rosyjskiego nacjonalizmu. Freski mogły stanowić dowód na „prymordialną"47 (odwieczną, $a b$ origine) obecność prawosławia i „rosyjskości” w Lublinie i na Lubelszczyźnie.

Granice świata „rdzennie rosyjskiego” były płynne. W epoce Kongresu wiedeńskiego linia podziału między guberniami zachodnimi imperium a Królestwem Polskim została wyznaczona wzdłuż Bugu, bardziej na północy zaś wzdłuż Niemna. Ponawiała ona granicę trzeciego rozbioru Rzeczypospolitej. Po 1863 r.

${ }^{44}$ M.M. PRZECISZEWSKA, „Between Empire and Nation: The social function of books in the Kingdom of Poland, 1864-1914”, Polish Libraries 7 (2019): 96-127.

${ }^{45}$ Wielce wymowna jest $\mathrm{w}$ tym sensie wypowiedź, wygłoszona $\mathrm{w}$ Warszawie $\mathrm{w}$ przededniu otwarcia Cesarskiego Uniwersytetu Warszawskiego przez hrabiego D.A. Tołstoja, ministra wychowania publicznego w imperium i w Polsce uchodzącego powszechnie za reakcjonistę, według którego rząd carski bynajmniej nie zamierzał przekształcać trzech milionów Polaków w rodowitych Rosjan. Rusyfikacja administracyjna miała za to „łagodzić nieporozumienia dzielące spokrewnione plemiona”, „Речь, произнесенная Графом Д.А. Толстым в Варшаве, 12 сентября 1868 года”, Журнал Министерства Народного Просвещения 139 (1868): 383-386, tu: 386. O otwarciu Cesarskiego Uniwersytetu Warszawskiego zob. A. SzWARC, „Akademia Medyko-chirurgiczna i Szkoła Główna 1857-1869” oraz J. SCHILLER-WALICKA, „Cesarski Uniwersytet Warszawski: między edukacją a polityką 1869-1917”, w Dzieje Uniwersytetu Warszawskiego 1816-1915, red. T. Kizwalter, P.M. Majewski (Warszawa: Wydawnictwa Uniwersytetu Warszawskiego, 2016), 415-555, 556-703; M. PicCIN, „Da "Scuola Superiore” a "Università Imperiale di Varsavia": genesi di un'università russa nel Regno di Polonia (1862-1869)", Annali di Ca' Foscari 45, nr 1 (2006): 151-189.

${ }^{46}$ Памятная книжка Люблинской губернии на 1903 г. (Люблин: Губернская типография, 1903), 98-100; „Люблин”, w Энииклопедический словар Брокгауз-Эфрон, t. XVIII (С.-Петербург: АО «Ф.А. Брокгауз - И.А. Ефрон», 1896), 215-216.

${ }^{47} \mathrm{Na}$ temat prymordializmu zob. N. BoŃCZA-TOMASZEWSKI, „Polskojęzyczni chłopi? Podstawowe problemy nowoczesnej historii chłopów polskich”, Kwartalnik Historyczny 112, nr 2 (2005): 91-111; ŁUCZEWSKI, Odwieczny naród. 
część nacjonalistycznie nastawionych intelektualistów rosyjskich zinterpretowała ustalenia Kongresu wiedeńskiego w świetle własnej ideologii, twierdząc, że kongresiści świadomie zaznaczyli granicę etniczną między Rosjanami a Polakami, lecz zapomnieli przy tym o „rosyjskiej” ludności Królestwa. Linia graniczna nie odzwierciedlała więc prawdziwego podziału między ludnością ruską (rosyjską) a polską; należało w związku z tym przesunąć ją na zachód od Bugu. Anonimowy publicysta z początku XX w. pisał:

Do 1815 r. zachodni Bug nie był granicą ani etnograficzną, ani wyznaniową, ani polityczną. Rzeka Bug, zaznaczona na Kongresie Wiedeńskim jako wschodnia granica „wskrzeszonego” Królestwa Polskiego, na znaczącej jej długości (górnej jak i dolnej) oddzielała Rosjan od Rosjan [sic! - M.P. ${ }^{48}$.

Przykładem podobnej argumentacji nowoczesnego nacjonalizmu rosyjskiego jest wypowiedź prawosławnego arcybiskupa chełmskiego Eulogiusza na temat roli Chełmszczyzny i kwestii granic Królestwa Polskiego. Jak inni Rosjanie po 1863 r., rosyjski hierarcha uważał, że wyznaczając granicę podczas Kongresu oddzielono Rosjan z prawego brzegu Bugu od Rosjan z lewego brzegu (zamieszkujących tzw. Zabuże), zaś władza rosyjska jakby „zapomniała" o Rusinach - czyli de facto o Rosjanach - po lewej stronie rzeki. Podczas obrad III Rosyjskiej Dumy Państwowej, kiedy przyjęto projekt wydzielenia Chełmszczyzny jako oddzielnej guberni ${ }^{49}$, Eulogiusz stwierdzał:

Ziemia chełmska była ofiarą nieporozumienia historycznego wtedy, kiedy granica Królestwa Polskiego została wytyczona w 1815 r. wzdłuż rzeki Bugu. Rosyjskie Zabuże zostało więc w taki sposób sztucznie oddzielone od Ojczyzny i zaczęło powoli przekształcać się w Polskie Przybuże $e^{50}$.

${ }^{48}$ К вопросу о выделении Холмской Руси (С.-Петербург, 1906), 1-2; И.П. Филевич, „Предисловие к Холмскому вопросу”, w Е.М. КРыжАновский, Русское Забужье (Холмшина u Подлящье) (С.-Петербург: Типография «Мирный труд», 1911), XXXV. Wśród polskich przeciwników tego ujęcia sprawy granicy Królestwa Polskiego należy wymienić m.in. Л. ДымшА, Холмский вопрос (С.-Петербург: Тип. Общественная Польза, 1910).

${ }^{49} \mathrm{Na}$ ten temat zob. np. Th.R. WEEKS, Nation and State in Late Imperial Russia. Nationalism and Russification on the Western Frontier, 1863-1914 (DeKalb: Northern Illinois University Press, 1996), szczególnie rozdział 9: The Dubious Triumph of Russian Nationalism. Formation of the Kholm Province, 172-192; por. też A. SzABACıUK, Rosyjski Ulster. Kwestia chetmska w polityce imperialnej Rosji wobec Królestwa Polskiego w latach 1863-1915 (Lublin: Wydawnictwo KUL, 2013), szczególnie rozdział 2: Problem chelmski w nowej odsłonie: masowy powrót dawnych grekokatolików do katolicyzmu, 67-115.

50 Государственная Дума 3-го созыва. Стенографические отчеты, Сессия V, ч. 1 (С.-Петербург, 1911-1912), kol. 2656. 
W podobnym duchu wypowiadał się Oberprokurator Świątobliwego Synodu, Konstantin Pobiedonoscew, wedle którego język, tradycje i kultura Chełmszczyzny były wyraźnie spokrewnione z kulturą pobliskiego Wołynia, Podola i Galicji. Ze stwierdzeniem tym zgadzali się zresztą wszyscy nacjonaliści rosyjscy pragnący udowodnić „rosyjskość” Zabuża ${ }^{51}$. Wytyczenie granicy pomiędzy Rosją i Królestwem Polskim wzdłuż Bugu nie odpowiadało logice nacjonalistycznej. Czy w takim razie najbardziej przesunięty na zachód kraniec terenów „rosyjskich” pokrywał się z naturalną granicą Bugu, czy sięgał tylko terenów bliskiej Chełmszczyzny? Dowody rosyjskości nacjonaliści byli w stanie znaleźć w wielu miejscowościach pomiędzy Bugiem a Wisłą, a w niektórych przypadkach - na zasadzie wyjątku - nawet za Wisłą:

Wedle wiarygodnych źródeł etnograficznych i historycznych granice narodowości ruskiej [русской народности] docierały ongiś do prawego brzegu Wisły; w dzisiejszej guberni Radomskiej, na wysokości Opatowa, owe granice przesuwały się nawet poza Wisłę. W tamtych szczęśliwych czasach odprawiano liturgię ruską przez ruskie duchowieństwo i dla ludu ruskiego; odprawiano liturgię w ruskich cerkwiach nie tylko na całym terenie prawego brzegu Wisły, ale także, według świadectwa Wołyńskiej kroniki, na lewym brzegu, w Sandomierzu i na wzgórzach Świętego Krzyża ${ }^{52}$.

Autorem tych słów, skierowanych w 1869 r. do carskiego ministra wychowania publicznego, hrabiego D.A. Tołstoja, był chełmski biskup greckokatolicki Michał Kuziemski. Ten wybitny przedstawiciel galickiego ruchu rusofilskiego ${ }^{53}$ inaczej rozumiał powrót grekokatolików do wiary ojców, czyli do prawosławia, i daleki był od utożsamiania rosyjskości z ruskością. Jednakże w oryginale jego tekstu nie sposób odróżnić pojęcia „ruski” od „rosyjski”,

${ }^{51}$ К.П. ПоБЕдОНосцЕВ, Историческая записка о Холмской Руси и городе Холме. О судьбах унии в Холмском крае и современном положении в нем униатского вопроса (С.-Петербург: Синодальная типография, 1902), 1-2. Por. też opinię innych publicystów rosyjskich: „Чествование членов Гос. Думы Холмским Св.-Богородицким братством 9 июня 1910 г.”, w Обзор русской периодической печати, вып. XVI: Холмский вопрос (С 1 Января 1909 г. по 1 Октября 1911 г.) (С.-Петербург: Государственная типография, 1912), 167.

52 Российский Государственный Исторический Архив (РГИА), С.-Петербург, zesp. 821, dz. 150, j. 759 (Переписка чиновника особых поручений при Министерстве Народного Просвещения по делам греко-униатского исповедания Ф.Ф. Кокошкина с Канцеларией по грекоуниатским делам и ее управляющим О.С. Сидорским об учреждении приходов в Холмской губернии и по другим вопросам, 27 авг. 1869 - 10 ноября 1869), k. 26-27.

${ }^{53} \mathrm{O}$ biskupie Kuziemskim zob. np. М.И. ГородЕцКий, „Последний греко-униатский епископ холмской епархии (Материалы для характеристики деятельности епископа Михаила Куземского)", w Памятники русской старины, вып. VIII: Холмская Русь (Люблинская и Седлецкая губ., Варшавского Генерал-Губернаторства) (С.-Петербург: Изд. Министерства Внутренних Дел, 1885), 504-530; Por. W. OsADCZY, Święta Ruś. Rozwój i oddziaływanie idei prawostawia w Galicji (Lublin: Wydawnictwo UMCS, 2007), 221-226. 
obydwa bowiem wyraża przymiotnik „русский” z podwójnym „,c”, a użycie tej właśnie formy tym bardziej podkreśla jedność ziem ruskich oraz ciągłość między Rusią Kijowską a współczesną Rosją. Domniemane cerkwie prawosławne w Sandomierzu i na Łysej Górze, wymienione w przytoczonym fragmencie listu Kuziemskiego, nie są wymysłem gorliwej antykatolickiej fantazji, lecz nawiązaniem do udokumentowanej obecności malarstwa ruskiego (a może również samego prawosławia) w kilku miejscach usytuowanych po stronie lewego brzegu Wisły. Chodzi tu o wspomniany już Kościół św. Krzyża na Łyścu (ob. Łysej Górze), którego ściany w latach 1393-1395 zdobili ruscy malarze, oraz o kościół katedralny w Sandomierzu, gdzie w 1887 r. w prezbiterium dokonano przypadkowego i rewelacyjnego odkrycia bizantyjsko-ruskich malowideł z epoki Władysława Jagiełły. Poza tym należy także dodać do tej listy freski w archikatedrze gnieźnieńskiej, w królewskiej sypialni Jagiełły na Wawelu i późniejsze, powstałe w czasach Kazimierza Jagiellończyka malowidła z kaplicy św. Stanisława w wawelskiej katedrze oraz freski w kolegiacie wiślickiej ${ }^{54}$.

Malowidła krakowskie były dobrze znane rosyjskim naukowcom. Już w 1822 r. Piotr Keppen, archeolog, historyk i badacz starożytności, wpisał kaplicę św. Krzyża do repertorium rosyjskich zabytków, niezbędnych do

${ }^{54}$ WALICKI, Malowidła ścienne kościoła św. Trójcy, 1-9; A. RÓŻYCKA-BRYZEK, „Bizantyńsko-ruskie malowidła ścienne w kolegiacie wiślickiej”, Folia Historiae Artium 2 (1965): 47-82; A. RÓŻYCKA-BRYZEK, „Bizantyńsko-ruskie malowidła ścienne w kaplicy Świętokrzyskiej na Wawelu (1470)”, Studia do Dziejów Wawelu 3 (1968): 175-293; S. STAWICKI, „Przyczynki do historii ściennych malowideł bizantyjsko-ruskich w Polsce. Technika i konserwacja”, Ochrona zabytków nr 47/1 (184) (1994): 3-21; M.P. KRUK, „Malowidła Graeco opere fundacji Jagiellonów jako postulat unii państwowej i kościelnej oraz jedności Kościoła”, w Między teologia a duszpasterstwem powszechnym na ziemiach Korony doby przedtrydenckiej. Dziedzictwo średniowiecza i wyzwania $X V-X V I$ wieku, red. W. Walecki (Warszawa: Wydawnictwo Uniwersytetu Warszawskiego, 2017), 145-201; J. ROKOSZNY, Średniowieczne freski w katedrze sandomierskiej (Kraków: Akademia Umiejętności, 1914); F. KoPERA, „O malarstwie byzantyńskiem w Polsce”, Polskie Muzeum 1, z. 8 (1914): 1-3; А.И. СоБОЛЕвский, Русские фрески в Старой Польше (Москва: Товарищество Типография А.И. Мамонтова, 1916); П. ЭттинГЕР, „Русская церковная стенопись в средневековой Польше”, Cтарые годы январь-февраль (1915): 69-72; A. WYRZYKOWSKI, „Zabytkowe freski w prezbiterium katedry sandomierskiej”, Kronika Diecezji Sandomierskiej 10 (1934): 277-287; S.W. MAKAREWICZ, „Fundacja i założenia programowe polichromii bizantyńskiej z bazyliki katedralnej w Sandomierzu”, Studia Theologica Varsaviensia 13, nr 2 (1975); S. GuRBA, „Zagadnienie recepcji bizantyńsko-ruskich malowideł bazyliki Sandomierskiej w epokach późniejszych", Studia Sandomierskie 21 (2014): 189-203; T. GIERGIEL, J. PTAK, „Fryz heraldyczny odkryty w katedrze sandomierskiej”, Rocznik Polskiego Towarzystwa Heraldycznego nowej serii nr 10 (21) (2011): 3-38; M. SMORĄG-RÓŻYCKA, „Bizantyńskie freski w sandomierskiej katedrze: królewski dar na chwałę Bożą czy odblask idei unii horodelskiej?”, Zeszyty Naukowe Uniwersytetu Jagiellońskiego. Prace Historyczne 141, z. 2 (2014): 235-255. 
stworzenia ojczystej nauki paleograficznej ${ }^{55}$. Lecz dopiero w 1875 r. S.M. Kryżanowski, członek Moskiewskiego Towarzystwa Archeologicznego, poddał szczegółowej analizie liczne ślady rosyjskiej kultury w Krakowie. Posługując się retoryką panslawistyczną, Kraków zaliczył do najwspanialszych miast Słowiańszczyzny, stwierdzając, że w stolicy Jagiellonów zachowało się kilka zabytków ruskich starożytności (русской старины) ${ }^{56}$. Według Kryżanowskiego w Krakowie liturgię odprawiano w języku słowiańskim dzięki misjonarzom benedyktynom z czeskiego klasztoru w Sazawie, którzy osiedlili się w Tyńcu i w kościele św. Krzyża na Kleparzu. Tradycja liturgii wschodniej miała trwać tutaj do XV w., do czasów Kazimierza Jagiellończyka, „znanego obrońcy języka staro-cerkiewno-słowiańskiego". Malarstwo bizantyjskie odgrywało ważną rolę szczególnie za czasów Jagiełły - wówczas zdobiono kościoły i komnaty (палаты) zamku na Wawelu ${ }^{57}$ - władcy wychowanego w otoczeniu kultury staroruskiej, z którą obcował w Wilnie, Trokach, Kijowie i Połocku. Kryżanowski wyliczał najważniejsze dokonania ruskich malarzy w Krakowie: malowidła w kaplicach św. Wojciecha i św. Stanisława na Wawelu, podkreślając, że wnętrze tamtejszej katedry było pierwotnie w całości ozdobione dziełami w stylu bizantyjskim. W takim stylu zbudowana została kaplica św. Trójcy, ufundowana przez Sofię Andriejewną, czwartą żonę Jagiełły, jednak w czasach, kiedy pisał Kryżanowski, nie nosiła już żadnych śladów bizantyjskich. Malowidła bizantyjsko-ruskie, pochodzące z drugiej połowy XV w., zachowały się jednak w Kaplicy Świętokrzyskiej, zwanej jeszcze w XIX w. „ruską”. Obydwie kaplice zostały prawdopodobnie zbudowane za czasów Jagiełły ${ }^{58}$.

$\mathrm{Na}$ temat fresków w katedrze na Wawelu wypowiadał się też znany uczony i działacz ukrainofil, Mikołaj Sumcow, przypisując ich autorstwo malarzom południoworuskim. Jego interpretacja powtarzała schemat argumentacji obecny u autorów wielkorosyjskich, tyle że opisując styl i warsztat artystów, pojęcie rosyjskości zastąpił „ukraińskością” (oficjalnie: „małorosyjskością”) ${ }^{59}$. Tego typu rozważania, optujące za prawosławnym rodowodem południowo-wschodniej części Polski, były jednak głosami odosobnionymi; nie znalazły systematycznej

\footnotetext{
55 П. КЕППЕН, Список русским памятникам, служащим к составлению истории художества отечественной палеографии (Москва: Типография С. Селивановскаго, 1822), 109.

${ }^{56}$ С.М. КрыжАновский, „Славянский Краков”, Древности. Труды Московского Археологического общества 6 (1876): 121.

${ }^{57}$ КрыЖАнОвский, „Славянский Краков”, 127-128.

${ }^{58}$ КрыжАновский, „Славянский Краков”, 132-134. Por. też Каринский, „Русская надпись в Люблинском тюремском костеле”, 131; СоБолЕвский, Русские фрески в Старой Польше, 3.

${ }^{59}$ Н.Ф. СумцОВ, Из украинской старины (Харьков: «Печ. Дело» кн. К.Н. Гагарина, 1905), szczególnie rozdział: К истории украинской иконописи, 3-4.
} 
wykładni w oficjalnym rosyjskim dyskursie nacjonalistycznym. Ślady prawosławia na zachód od Wisły nie były wystarczającym argumentem, który przemawiałby za depolonizacją zachodnich guberni Królestwa Polskiego; stąd po stronie władzy carskiej brak zamiarów rusyfikacji innych niż wschodnie terenów Królestwa Polskiego.

W drugiej połowie XIX w. debata nad „rosyjskością” odnosiła się przede wszystkim do wschodnich terenów Królestwa Kongresowego. Na ziemi chełmskiej i podlaskiej po 1863 r. prowadzono systematyczne prace nad odkrywaniem śladów starożytności rosyjskich. Ich dokumentacje miały być fundamentem dla formułowania naukowych (lub pseudonaukowych) podstaw dla rosyjskich dążeń nacjonalistycznych. Tendencje te sięgały pierwszej połowy XIX w., kiedy to rosyjskie elity i rozwijająca się inteligencja o różnym rodowodzie zaczęły patrzeć na historię swego kraju nieco inaczej niż wcześniej. Impuls do zmiany perspektywy dała wspomniana już Istorija rossijskaja Mikołaja Karamzina, oficjalnego historyka dworu Aleksandra I, w której wybrzmiał postulat zebrania wszystkich ziem należących niegdyś do dziedzictwa świętego Włodzimierza. Inspiracją dla tych samych dążeń były znane studia historyczne Nikołaja Ustrjałowa oraz wielokrotnie wznawiane podręczniki szkolne Dymitra Iłowajskiego, kształcące w duchu nacjonalizmu całe pokolenia Rosjan i wprowadzające pierwsze wzmianki o czynniku etnicznym w kontekście zachodnich kresów imperium ${ }^{60}$.

Katalog starożytnych zabytków rosyjskich guberni zachodnich, zainicjowany już w latach 50. XIX w. przez nacjonalistycznie nastawionych urzędników carskich, mógł się tym samym wzbogacić o dzieła architektury, sztuki i literatury, które miały stanowić dowód pierwotnej rosyjskości tych terenów; rosyjskości już nie tylko w rozumieniu dynastycznym, lecz przede wszystkim etniczno-wyznaniowym. Wśród najważniejszych prac, powstałych w wyniku procesu katalogowania kulturowego dziedzictwa imperium, warto wymienić wielotomową serię Памятники русской старины в западных губерниях, wydawaną pod redakcją petersburskiego urzędnika Pompejusza Batiuszkowa (przyrodniego brata poety Konstantina). Dwa tomy tej serii, które ukazały się w latach 80. XIX w., poświęcone zostały tzw. Rusi Chełmskiej. W powstawaniu dzieła wzięli udział przedstawiciele rosyjskiej elity akademickiej i Cerkwi prawosławnej, działający m.in. na Chełmszczyźnie (np. gorliwy

${ }^{60} \mathrm{~K}$. BŁACHOwSKA, Wiele historii jednego państwa. Obraz dziejów Wielkiego Księstwa Litewskiego do 1569 roku w ujęciu historyków polskich, rosyjskich, ukraińskich, litewskich i białoruskich w XIX wieku (Warszawa: Neriton, 2009), 71-89; M.M. PRZECISZEWSKA, „Naród, imperium, narracja. Podręczniki do historii Dymitra Iłowajskiego jako narzędzie rosyjskiej „polityki czytelniczej” w Królestwie Polskim", Slavia Orientalis 64, nr 1 (2015): 35-50. 
prawosławny biskup lubelski Modest) oraz księża prawosławni byłej chełmskiej diecezji greckokatolickiej i nauczyciele szkół prawosławnych dla ludu, otworzonych po kasacie diecezji w 1875 r. W tomach dotyczących Rusi Chełmskiej, podobnie jak w innych dziełach poświęconych starożytnościom rosyjskim ${ }^{61}$, znalazły się artykuły na temat średniowiecznych wież zlokalizowanych na pograniczu polsko-litewsko-ruskim (np. wieże w Kamieńcu Litewskim, w Stołpiu i w Bieławinie pod Chełmem). Litograficzne reprodukcje wież Chełmszczyzny umieszczano w licznych publikacjach (w większości raczej popularnych niż naukowych, a zatem propagandowych), dotyczących historii i tradycji ziemi chełmskiej jako rdzennie rosyjskiej i prawosławnej. Rosyjscy historycy i publicyści nie mieli wątpliwości: budowle powstały w czasach panowania książąt ruskich (Daniela Romanowicza lub nawet władców wcześniejszych), co potwierdza ich rosyjską genezę...

Słabiej jednak udokumentowana jest rosyjskość okrągłej wieży (donżona) na wzgórzu zamkowym w Lublinie, której nacjonaliści rosyjscy nie zaliczyli do sieci wież obronnych, chroniących ruskie ziemie przed najazdami Litwinów czy Polaków. Zabytek ów nie należał do obszaru wyobrażonej geografii rosyjskiej, a więc nie był przedmiotem dyskursu nacjonalistycznego ${ }^{62}$. Nawet opisany przez Długosza epizod zajęcia przez Daniela Romanowicza wzgórza zamkowego uznano - jak się zdaje - za chwilowy i może dlatego nie do końca wiarygodny epizod rosyjski w historii Lublina, który później znalazł się definitywnie w rękach polskich ${ }^{63}$. Takie ujęcie pojawia się np. u ukraińskiego

${ }^{61}$ А.В. Лонгинов, „Памятники русской старины в г. Люблине”, w Памятники русской старины в западных губерниях, вып. VIII: Холмская Русь, red. П.Н. Батюшков (С.-Петербург: Издание Министерства Внутренних Дел, 1885), 209-260.

${ }^{62}$ Dowodem na to, że baszty w Lublinie nie zaliczano do zabytków rosyjskiej stariny, jest stwierdzenie Fieofana Lebiedincewa, dyrektora szkolnego w Chełmie w latach 1865-1871, gorliwego rusyfikatora grekokatolików diecezji chełmskiej. Opuszczając Chełm w 1871 r., żeby objąć stanowisko dyrektora szkolnego w Radomiu, Lebiedincew został odprowadzony przez delegację urzędników i uczniów chełmskich szkół do Stołpia. Tu miał powiedzieć: „Oto tysiącletnia wieża! Tu bez wątpienia przebiegała granica ziemi i osiedleń rosyjskich. Jadę do Polski” [podkr. M.P.]. To, że owa granica wyobrażonej ziemi rosyjskiej była jednak płynna, potwierdzają słowa tego samego Lebiedincewa, który, przy tej samej okazji, życzył sobie, aby przesunięto jeszcze bardziej na zachód „magiczną” granicę świata rosyjskiego. Por. M. PICCIN, „Lieux de Mémoire na pograniczu polsko-ruskim: przypadek Ziemi Chełmskiej (po 1863 r.)", Przegląd Środkowo-Wschodni 5 (2020): 9-43.

${ }^{63}$ Jak zauważyła Irena Kutyłowska: „Różnego typu publikacje - szczególnie popularnonaukowe - do połowy lat 60., [np. I. BuczkowA, Zamek Lubelski (Lublin: Muzeum Okręgowe, $1969)$ - uzup. M.P.] przypisywały jej [wieży] wzniesienie księciu halicko-wołyńskiemu Danielowi Romanowiczowi, który miał w 1243 lub 1244 zająć Lublin i władać nim do 1246 lub 1256 r. Pogląd ten oparty był głównie na XVI-wiecznej relacji Długosza, który podaje pod rokiem 1244: »Książę ruski Daniel przy nadarzającej się okazji zajmuje nieszczęsne miasto Lublin i jego zamek. Książę ruski i kijowski Daniel, dowiedziawszy się o spustoszeniu i wyludnieniu ziemi 
historyka A.W. Storożenki, pochodzącego ze starego rodu wywodzącego się ze starszyzny kozackiej. Choć był on wrogo nastawiony do kultury polskiej ${ }^{64}$, to jednak w artykule, opublikowanym w 1906 r. w Чтениях в Историческом Обществе Нестора летописиа, historię Lublina - bez śladów uprzedzeń przedstawił jako część historii Polski ${ }^{65}$.

Jeśli więc średniowieczna wieża nie była wystarczającym dowodem na pierwotną rosyjskość Lublina, mogły stać się nim bizantyjskie malowidła w kaplicy Świętej Trójcy, tym samym przyczyniając się do przesunięcia wyobrażonej granicy nacjonalizmu rosyjskiego.

\section{ODKRYCIE FRESKÓW W KAPLICY ŚWIĘTEJ TRÓJCY NA ZAMKU LUBELSKIM A ICH INTERPRETACJA}

Jak już wiadomo, pierwszych wzmianek o istnieniu fresków dostarczył w połowie XIX w. Stronczyński podczas inwentaryzacji zabytków Królestwa,

lubelskiej, przybywa z wojskiem do Lublina, zajmuje zarówno zamek jak miasto, a całą ziemię lubelską przywłaszcza sobie i nieprawnie zajmuje. I ażeby jej zagarnięcie uczynić trwalszym dla siebie i swoich potomków, buduje z podziwu godną szybkością w środku zamku okrągłą wieżę z wypalonych cegieł, z obejściem i blankami na szczycie. Umacnia zamek oraz miasto Lublin wałami i głębokimi rowami, a całe rycerstwo i mieszkańców ziemi lubelskiej zmusza do uległości« (J. DŁugosz, Roczniki czyli kroniki sławnego Królestwa Polskiego, księga VII i VIII, t. 4, Warszawa 1974, s. 57). Jednak ruskie źródła (Kronika halicko-wołyńska, Latopis wołyński) »nic nie mówią o władaniu ks. Daniela w Lublinie, jak również o podjętej przez niego działalności budowlanej w tym grodzie [...] Niemożliwe jest, aby pominięte zostało w nich takie wydarzenie, jak opanowanie Lublina, nie mówiąc już o władaniu nim przez kilka lat, tym bardziej, że latopis opisuje wydarzenia z 1243 r. i początku 1244 r. szczegółowo«”. Autorka nie wyklucza możliwości identyfikowania wieży opisywanej w źródłach (u Długosza i w Roczniku świętokrzyskim vel Roczniku mansjonarzy krakowskich) z opisanym w Latopisie wotyńskim grodem na wzgórzu w Chełmie. Por. I. KutYŁowsKA, „Nowe spojrzenie na dzieje Zamku lubelskiego w średniowieczu”, Region Lubelski nr 2 (4) (1987): 153-162. Wedle tej autorki okrągłą więżę należy przypisać Bolesławowi Wstydliwemu; zdaniem innych badaczy wieża została zbudowana dopiero za panowania Władysława Jagiełły. Por. S. KuRAś, „Kiedy zbudowano okrągłą wieżę Zamku lubelskiego?", w Problemy historii i archiwistyki, red. T. Mencel (Lublin: Wydawnictwo UMSC, 1986), 13-14 oraz najnowsze studium poświęcone temu tematowi: J. CHACHAJ, „Czas podjęcia budowy wieży zamkowej w Lublinie w świetle najnowszych badań archeologicznych”, Kwartalnik Historii Kultury Materialnej 67, nr 3 (2019): 307-322.

${ }^{64}$ Storożenko wyróżniał się wiernością imperium rosyjskiemu, był przeciwnikiem Ukrainofilstwa. Por. А.В. СтоРоженко, Происхождение и сущность украинофильства (Киев: Типография С.В. Кульженко, 1912); А.В. Стороженко, Малая Россия или Украина? (Ростов над Донем, 1919).

${ }^{65}$ А.В. СторожЕнко, „Древности г. Люблина”, w Чтения в Историческом Обществе Нестора Летописиа, кн. 19, отд. II, вып. 2-ой (Киев: Типо-литграфия Т.Г. Меинандера, 1906), 35-49, tu: 43-45. Storożenko uważał freski w kaplicy zamkowej za wyraz południoworuskiego rozgałęzienia malarstwa kijowskiego. Рor. СоБолЕвский, Русские фрески в Старой Польше, 4. 
lecz ich pełne odkrycie nastąpiło w 1897 r. dzięki Józefowi Smolińskiemu. O swym znalezisku Smoliński poinformował Akademię Umiejętności w Krakowie. Rok później starania o odnowienie malowideł podjął Antoni Strzalecki, lubelski malarz i dekorator, co zwróciło uwagę gubernatora lubelskiego Włodzimierza Tchórzewskiego. Dzięki jego raportowi do władz petersburskich, w 1903 r. sprawa fresków lubelskich była przedmiotem dyskusji w Instytucie Archeologicznym przy Cesarskiej Komisji Archeologicznej w Petersburgu. W listopadzie tegoż roku delegacja złożona z dyrektora Instytutu archeologicznego, Nikołaja Wasilewicza Pokrowskiego, oraz członka komisji, Piotra Piotrowicza Pokryszkina, udała się do Lublina w celu przebadania stanu fresków w kaplicy zamkowej. Pod nadzorem Pokrowskiego i Pokryszkina zdjęto część tynku i odsłonięto kolejne fragmenty malowideł (zob. ilustracja nr 2).

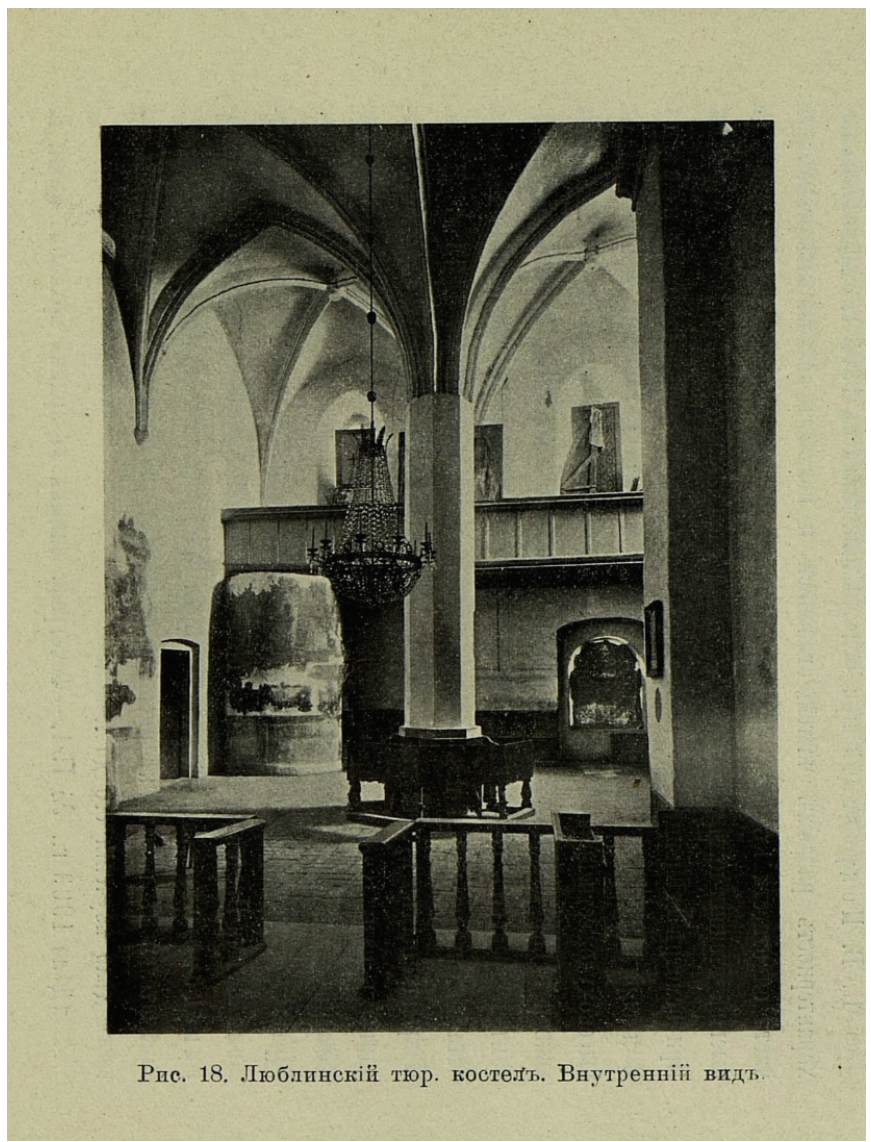

Rysunek 2. Widok wewnętrzny kaplicy (widoczne fragmenty odsłoniętych fresków, zdjęcie najprawdopodobniej z 1903 r.) 
Delegacji petersburskiej towarzyszył miejscowy badacz zabytków rosyjskich Fiodor Korałłow, nauczyciel w chełmskim seminarium duchowym, gorliwy zbieracz ruskich starożytności oraz kustosz Cerkiewno-archeologicznego muzeum przy Bractwie św. Bogurodzicy w Chełmie.

Aby zrozumieć podejście miejscowych działaczy do kwestii rosyjskości terenów wschodnich Królestwa Polskiego, warto przytoczyć słowa, które w 1907 r., z okazji 25-lecia otwarcia muzeum, Korałłow zawarł w opisie chełmskiego sancta sanctorum rosyjskiej stariny: „Nie poprzez księgi i martwą literę, gołe słowa i frazesy, lecz poprzez zabytki naszych starożytności oraz dzieła żywych ludzi przejawia się udręczony los naszych kresów" ". Po pobycie w Lublinie delegacja w towarzystwie Korałłowa udała się do Chełma, gdzie poświęciła jeden dzień na zwiedzanie tamtejszych starożytności ${ }^{67}$.

W 1904 r. lubelskie freski zostały zbadane przez uczonego Uniwersytetu Jagiellońskiego, Mariana Sokołowskiego, który zezwolenie na przeprowadzenie badań dostał od petersburskiej Komisji Archeologicznej. Wyniki jego pracy zostały przedstawione na zebraniu Komisji do Badania Historii Sztuki w Polsce. Sokołowski zauważył podobieństwa pomiędzy odsłoniętymi fragmentami malowideł a freskami powstałymi za czasów Jagiełły i Kazimierza Jagiellończyka $^{68}$. W latach późniejszych kwestia dalszego odkrywania i konserwacji fresków przeciągała się. Dopiero w 1914 r. Cesarska Komisja Archeologiczna wysłała ponownie do Lublina P.P. Pokryszkina oraz restauratora malarstwa ikonowego Michaiła Josifowicza Czirikowa z Moskwy. Rezultatem tej wizyty była skierowana do Ministerstwa Sprawiedliwości prośba o środki na odnowienie fresków. Pozostała jednak bez odpowiedzi. Wiemy tylko, że przewodniczący Komisji Archeologicznej w Petersburgu i członek Cesarskiego Rosyjskiego Towarzystwa Geograficznego, hrabia Aleksiej Aleksiejewicz Bobrinski, zalecał, aby dalsze odsłanianie fresków w kaplicy zamkowej zostało przeprowadzone przez miejscowych specjalistów, na czele z Fiodorem Korałłowem. Życzenie to jednak nie mogło się spełnić z powodu wybuchu

${ }^{66}$ Ф.В. КОРАЛЛОв, Церковно-археологический мизей при Холмском Православном СвятоБогородииком Братстве (Холм: Холм. Св.-Богородиц. братство, 1911), 8-9.

${ }^{67}$ „КРАТКИЙ отчет по церковно - археологическому музею и библиотеке при нем за 1903 904 братский год”, Холмско-Варшавский Епархиальный Вестник 19, nr 9 (27.II.1905): 112-113; „Отчет о состоянии и деятельности находящегося под Высочайшим Его Императорского Величества покровительством Холмского Православного Свято-Богородицкого Братства за 1903-4 (двадцать пятый) братский год”, Холмско-Варшавский Епархиальный Вестник 19, nr 10 (6.III.1905): 123-126.

${ }^{68}$ Sprawozdania Komisji do Badania Historii Sztuki w Polsce 8 (1912), szp. 370. 
I wojny światowej ${ }^{69}$. Ostateczne odkrycie malowideł i akcja konserwatorska miały miejsce już po wycofaniu urzędów rosyjskich z Królestwa w pierwszych latach II Rzeczypospolitej (1918-1923).

Według pierwszych hipotez dotyczących pochodzenia malowideł, sformułowanych przez badaczy rosyjskich z Cesarskiej Komisji Archeologicznej, historia kaplicy, będącej pierwotnie świątynią prawosławną, sięgała epoki Daniela Halickiego, a polichromia była owocem zbiorowej pracy kilku pokoleń artystów pomiędzy XIII a XV w. Ze względu na wyjątkowość tego zabytku należało przekształcić ówczesną kaplicę więzienną w muzeum i przeprowadzić niezbędne prace konserwatorskie. W 1905 r., w notatce opublikowanej w gazecie Санкт-Петербургские ведомости i przedrukowanej w biuletynie Cesarskiej Komisji Archeologicznej (w dodatku do tomu 14), pisano o tym odkryciu jako o zabytku dawnej słowiańskiej kultury i sztuki, unikacie słowiańskiej archeologii ${ }^{70}$. Co więcej, ta sama Cesarska Komisja Archeologiczna, jeszcze w 1914 r., w osobie petersburskiego językoznawcy Nikołaja Karinskiego stwierdziła, że napis fundacyjny odkryty w 1903 r. należało przypisać pędzlowi „małoruskiego” malarza (малоросса) ${ }^{71}$.

Jeszcze bardziej znaczące są uwagi sformułowane przez wspomnianego już Korałłowa w piśmie urzędowym Люблинские губернские ведомости z 1903 i 1904 r. ${ }^{72}$ Według Korałłowa, który nieco inaczej niż Cesarska Komisja rozłożył akcenty, malarstwo to nosiło ślady dawnego, wielkiego staroruskiego malarstwa ikonowego; niektóre jego cechy, np. długość szat liturgicznych (omoforion) przedstawionych na freskach, wskazywały na pochodzenie ruskie. Styl malowideł był staroruski (старорусских приемов иконографической $\kappa и с т и)$, a zatem stanowiły one zabytek ikonografii słowiano-ruskiej ${ }^{73}$. Korałłow nie operował kategoriami wielko- czy małorosyjskimi; przymiotnik „русский” pozwolił mu rzucić pomost między światem staroruskim a „współczesno-ruskim”

${ }^{69}$ Zob. Komunikat z 1914 r. (Протоколы реставрационных заседаний - заседание 20 февраля) pt. „Г. Люблин. Тюремный костел. Стенопись 1413 г.” Cesarskiej komisji archeologicznej o stanie badań nad freskami, Известия Императорской Археологической Коммиссии, вып. 55-й (Петроград, 1914), 25-29.

${ }^{70}$ Известия Императорской Археологической Коммиссии, прибавление к выпуску 14-му (С.-Петербург, 1905), 33-34.

${ }^{71}$ КАРИНСКИй, „Русская надпись в Люблинском тюремском костеле”, 131.

72 Люблинские губернские ведомости, nr 263, 285, 287 (1903); nr 5 (1904); tekst opublikowany też w Ф.В. Кораллов, „Памятник древне-русской иконописи, сохранившийся в часовне Св. Тройцы города Люблина”, w Памятная Книжка Люблинской губернии на 1904 г. (Люблин: Губернская типография, 1904), 1-25.

${ }^{73}$ КОРАЛЛОВ, „Памятник древне-русской иконописи”, 1, 4, 9, 25; por. też „Краткий отчет по церковно - археологическому музею”; Отчет о сотоянии и деятельности. 
(rosyjskim), które miały współistnieć w doskonałej ciągłości oraz jedności „przeszłości, teraźniejszości i przyszłości” narodu rosyjskiego.

Według Korałłowa budowę zarówno wieży, jak i kościoła - a dokładniej: „cerkwi” - na wzgórzu zamkowym należało przypisać Danielowi Halickiemu. Stwierdzenie to było poparte świadectwami z kroniki Długosza i Latopisu Wołyńskiego oraz faktem, że miejscowi mieszkańcy Lublina nazywali wieżę „Danielowską"74. Nie przypadkiem hrabia Bobrinski życzył sobie, aby dalsze badania nad freskami zostały przeprowadzone przez miejscowych specjalistów, którzy niewątpliwie lepiej rozumieliby potrzeby nacjonalizmu rosyjskiego na zachodniej peryferii imperium. U Korałłowa odnajdujemy więc najbardziej nacjonalistycznie zorientowaną interpretację fresków lubelskich. Ich odkrycie opisywał, posługując się bardzo znamienną analogią: tak jak spod warstwy tynku odsłaniano stopniowo ocalałe arcydzieło rosyjskiej sztuki, tak samo spod zasłony „strasznej katolicko-unickiej burzy” mogły wreszcie wychodzić na jaw zdrowe nienaruszone elementy ruskiej (rosyjskiej) tożsamości.

Ugruntowaniu przekonania o rosyjskości nowego odkrycia sprzyjały dalsze przedsięwzięcia rosyjskich działaczy i poszukiwaczy zabytków ruskich starożytności. Odnalezienie fresków było powodem, żeby od instytucji petersburskich - jak się zdaje nie zawsze świadomych żądań działającej na peryferiach imperium elity - domagać się skierowania większej uwagi na działalność miejscowych rusyfikatorów. W takim duchu utrzymana jest notatka prasowa, odnaleziona przez H. Bilewicza wśród papierów Cesarskiej Komisji Archeologicznej, która (moim zdaniem) mogła wyjść spod pióra albo samego Korałłowa, albo osoby zajmującej się bezpośrednio ruskimi starożytnościami na zachodnich kresach imperium:

[kaplica zamkowa] nosi wszelkie cechy cerkwi przekształconej na kościół, jednak zachowującej ślady prawosławia. Co robi nasze Towarzystwo Archeologiczne, w obowiązku którego leży troszczenie się o resztki bez wątpienia ruskich zabytków, szczególnie w miejscach, gdzie toczy się walka narodowa? Czy wie ono o istnieniu bardziej interesujących licznych wież koło Chełma, które wiążą się z czasami Daniela Halickiego a być może są i starsze? Te rzadkie, bez wątpienia ruskie zabytki niszczeją z roku na rok i giną, kamienie z nich roznoszą Żydzi i Polacy itd. A przecież są to ruskie pamiątki na rubieżach ruskiej ziemi, mówiące o Włodzimierskiej Rusi ${ }^{75}$.

\footnotetext{
${ }^{74}$ Отчет о сотоянии и деятельности, 126. Por. już wymieniony komunikat „Г. Люблин. Тюремный костел”, w którym czytamy: «Некоторые историки полагают, что нынешний костел переделан из православной часовни, существовавшей при дворце Даниила Галицкого во второй половине XIII ст.», 26, 28.

${ }^{75}$ Cyt. za H. BILEwICZ, „Między Krakowem a Petersburgiem. Casus bizantyńsko-ruskich malowideł lubelskich w pierwszych dekadach XX wieku”, w Kaplica Trójcy świętej na Zamku
} 
Tego rodzaju rosyjskie interpretacje zabytku lubelskiego wywołały oczywiście reakcję polskich specjalistów. Odkrywca malowideł, Józef Smoliński, w 1907 r. pisał o nielogicznym przypuszczeniu,

że to była kiedyś cerkiew, jak to przypuszczali przypadkowi i miejscowi znawcy [podkr. M.P.], dopatrując się w malowanej tablicy wotywnej, najpierw przeze mnie odkrytej w r. 1899 cech stylu cerkiewnego i tym sposobem robiąc mnie odpowiedzialnym za przyczynienie się do zabrania tego kościoła na cerkiew prawosławną z jakiego to powodu miałem rozmaitej natury przykrości ${ }^{76}$.

Krytykę interpretacji rosyjskich uczonych sformułował też filolog Hieronim Łopaciński, korygując niektóre niedokładności chronologiczne i archeologiczne. Na malowidła staroruskie zapatrywał się „nie tylko jako na bardzo cenny zabytek archeologiczny, ale również jako na jedno jeszcze bardzo ważne świadectwo historyczne o wpływie wzajemnym kultury dwóch sąsiednich narodów słowiańskich" "77. Zaproszenie do Polski artystów ruskich w XIV i $\mathrm{XV}$ w. porównywał z dużo późniejszą artystyczną działalnością polskich malarzy w świątyniach Rosji: np. Siemiradzkiego w Moskwie w Cerkwi Zbawiciela; Kotarbińskiego w Kijowie w soborze św. Włodzimierza; Andriollego w Wiatce. Zaprzeczał poza tym, jakoby kościół zamkowy sięgał czasów Daniela Halickiego; według niego kaplica murowana została zbudowana najwcześniej w XIV w., czego dowodem jest rodzaj cegły, a w szczególności styl budowli, tak charakterystyczny dla epoki panowania Kazimierza Wielkiego. Twierdzenie, że świątynia była początkowo cerkwią, dopiero na początku XV w. zmienioną na świątynię katolicką, było sprzeczne z dokumentami, w których w 1326 r. budowę przedstawiono jako kościół katolicki ${ }^{78}$.

Analiza rosyjskich wypowiedzi na temat fresków lubelskich pozwala na sformułowanie uwag końcowych. Debata nad pochodzeniem oraz kulturowym i politycznym znaczeniem zabytku była stosunkowo ograniczona, zwłaszcza jeśli porównać ją z dyskusjami na temat rosyjskich starożytności ziemi chełmskiej. W ciągu kilkunastu lat od chwili odkrycia malowideł rosyjscy historycy i publicyści raczej słabo wykorzystali „ideologiczny” potencjał

Lubelskim. Historia, teologia, sztuka, konserwacja. Materiaty sesji zorganizowanej w Muzeum Lubelskim 24-26 kwietnia 1997 roku, red. B. Paprocka, J.A. Sil (Lublin: Muzeum Lubelskie, PTTK Oddział w Lublinie, 1999), 175-207, tu: 183-184.

${ }^{76}$ Cyt. za Bilewicz, „Między Krakowem a Petersburgiem”, 183.

${ }^{77}$ H. ŁOPACIŃSKI, „Z powodu odkrycia zabytków malarstwa starożytnego w kościele świętej Trójcy w Lublinie", Gazeta Lubelska nr 67 (1904): 1-2; nr 68 (1904): 1-2; nr 69 (1904): 1-2, tu: 2.

${ }^{78}$ ŁOPACIŃSKI, „Z powodu odkrycia zabytków”. 
staroruskiego zabytku o takim walorze artystycznym. Trudności w znalezieniu wystarczających środków finansowych na konserwację malowideł, przy jednoczesnym (jak się zdaje) braku szczególnego zainteresowania ze strony instytucji petersburskich, spowodowały, że nawet w przededniu I wojny światowej nie planowano akcji konserwatorskiej. Dopiero w 1914 r., kiedy po kilkuletniej przerwie wrócono do tej sprawy, Pokryszkin miał stwierdzić, że:

honoru zbadania fresków - które mogą pochodzić z XIII w., to znaczy z czasów przynależności Lublina do Rusi - nie można odstąpić obcym uczonym nastawionym tendencyjnie. Wypełnienie tej pracy jest moralnym obowiązkiem rosyjskiej nauki ${ }^{79}$.

Te wymowne słowa poświadczają, że w środowiskach petersburskich dopiero u progu I wojny światowej zaczęto uważać Lublin za miasto o rodowodzie rosyjskim, przesuwając tym samym wyobrażoną granicę nacjonalizmu rosyjskiego. Jego doktryna rozwijała się najwyraźniej w tempie nieśpiesznym, potwierdzając diagnozę o „nieznośnej powolności” ${ }^{80}$ machiny imperium. Jak się więc okazuje, carskie narzędzia rusyfikacji narodowej nie były, w ostatecznym rozrachunku, szczególnie skuteczne.

${ }^{79}$ BiLEwicz, „Między Krakowem a Petersburgiem”, 184. Polscy specjaliści zdecydowanie skrytykowali metody konserwatorskie stosowane przez komisję petersburską. Według Stanisława Tomkowicza $\mathrm{z}$ Komisji do badania historii sztuki w Polsce napis fundacyjny zawierający tytulaturę królewską Jagiełły zeskrobał i zniweczył pewien badacz rosyjski; według Michała Walickiego stało się to na skutek ,zrozumiałego zapału odkrywców”. Hubert Bilewicz jednak stwierdza, że nie można z całkowitą pewnością przypisać zniszczenia części fresków wyłącznie brakowi kompetencji rosyjskich badaczy, trzeba także wziąć pod uwagę pewne nastawienie nacjonalistyczne polskich uczonych. Lubelski poeta Józef Czechowicz pisał: „Kościół św. Trójcy to jeden z najpiękniejszych w Polsce zabytków. Zbudowany z niezwykłym umiarem, pokryty bardzo pięknymi freskami, które, niestety w dużej części zniszczyło barbarzyństwo rosyjskich władz zaborczych, stanowi skarb Lublina”, S.C. [Józef Czechowicz], „Stary i nowy Lublin. Krótki przewodnik po naszym mieście”, dodatek do Expressu Lubelskiego: „Kalendarz na rok 1928”, 88, cyt. za: Scriptores: pamięć, miejsce, obecność: laboratorium pamięci, małe ojczyzny, spotkania kultur nr 32 (2008): CZECHOWICZ - w poszukiwaniu ukrytego miasta, cz. 3: 223-224. Zafascynowany freskami Czechowicz wspólnie z Franciszką Arnsztajnową poświęcił kaplicy piękny wiersz „Kościół Świętej Trójcy” (w Stare Kamienie, Lublin: Lubelskie Towarzystwo Miłośników Książki, 1934) oraz tekst „Kościół na Zamku w Lublinie”, Przegląd LubelskoKresowy nr 4 (1925): 2-3. Por. też Czechowicza „Wyobraźnia stwarzająca”, w idem, Wyobraźnia stwarzająca. Szkice literackie, oprac. T. KŁAK (Lublin: Wydawnictwo Lubelskie, 1972), 88-89.

${ }^{80}$ O nieznośnej, czy wręcz „skandalicznej” powolności rosyjskiej polityki imperialnej, ze szczególnym uwzględnieniem syberyjskich okrain państwa carów, przekonująco pisze A. MASOERO, „L'insostenibile lentezza dell'Impero zarista. Catasti e arte del governo in Transbaikalia”, Rivista Storica Italiana 130, fasc. 1 (2018): 118-163. 


\section{BIBLIOGRAFIA}

\section{ŹRÓDŁO ILUSTRACJI}

Izvestiya Imperatorskoy Arkheologicheskoy Kommissii, vyp. 55-y, 26 i 27. Petrograd, 1914. Ze zbiorów cyfrowych Biblioteki Prezydenckiej im. B.N. Jelcyna: https://www.prlib.ru/item/1057303.

\section{ŹRÓDŁA ARCHIWALNE}

Rossiyskiy Gosudarstvennyy Istoricheskiy Arkhiv (RGIA). S.-Peterburg, zesp. 821, dz. 150, j. 759, Perepiska chinovnika osobykh porucheniy pri Ministerstve Narodnogo Prosveshcheniya po delam greko-uniatskogo ispovedaniya F.F. Kokoshkina s Kantselariyey po greko-uniatskim delam i yeë upravlyayushchim O.S. Sidorskim ob uchrezhdenii prikhodov v Kholmskoy gubernii i po drugim voprosam, 27avg. 1869 - 10 noyabrya 1869.

\section{ŹRÓDEA DRUKOWANE}

Album Lubelskie. Rysowat z natury i opisat A. Lerue. Poszyt I. Warszawa: A. Pecq et Comp., 1857.

Album Widoków Historycznych Polski poświęcony Rodakom zrysowany z natury przez Napoleona Ordę. Warszawa: Gebethner \& Wolff, 1873-1883.

ANUCHIN, Dmitry Nikolaevich. O zadachakh russkoy etnografii (Neskol'ko spravok i obshchikh zamechaniy), kn. I. Moskva: «Russkaya» tipo-lit., 1889.

ARnszTajnowa, Franciszka i Czechowicz Józef. Stare Kamienie. Lublin: Lubelskie Towarzystwo Miłośników Książki, 1934.

„Chestvovaniye chlenov Gos. Dumy Kholmskim Sv.-Bogoroditskim bratstvom 9 iyunya 1910 g.”. W Obzor russkoy periodicheskoy pechati. Vyp. XVI: Kholmskiy vopros (S 1 Yanvarya 1909 g. po 1 Oktyabrya 1911 g.). S.-Peterburg: Gosudarstvennaya tipografiya, 1912.

Czechowicz, Józef. „Kościół na Zamku w Lublinie”. Przegląd Lubelsko-Kresowy nr 4 (1925): 2-3.

CzeCHOwICZ, Józef. Wyobraźnia stwarzająca. Szkice literackie, oprac. T. Kłak. Lublin: Wydawnictwo Lubelskie, 1972.

ETTINGER, Pavel Davidovich. „Russkaya tserkovnaya stenopis’ v srednevekovoy Pol'she”. Staryye gody yanvar'-fevral' (1915): 69-72

FILEVICH, Ivan Porfirevich. „Predisloviye k Kholmskomu voprosu”. W Y.M. Kryzhanovskiy, Russkoye Zabuzh 'ye (Kholmshchina i Podlyash 'ye), V-XLVI. S.-Peterburg: Tipografiya «Mirnyj trud», 1911.

„G. Lyublin. Tyuremnyy kostel. Stenopis' 1413 g.”. W Izvestiya Imperatorskoy Arkheologicheskoy Kommissii, vyp. 55-y, 25-29. Petrograd, 1914.

GORODETSKIY, Mitrofan Ivanovich. „Posledniy greko-uniatskiy yepiskop kholmskoy yeparkhii (Materialy dlya kharakteristiki deyatel'nosti yepiskopa Mikhaila Kuzemskogo)". W Pamyatniki russkoy stariny, vyp. VIII: Kholmskaya Rus' (Lyublinskaya i Sedletskaya gub., Varshavskogo General-Gubernatorstva), red. P. Batyushkov, 504-530. S.-Peterburg: Izdaniye Ministerstva Vnutrennikh Diel, 1885.

Gosudarstvennaya Duma 3-go sozyva. Stenograficheskiye otchety, Sessiya V, ch. 1. S.-Peterburg, 1911-1912, kol. 2656

Dymsha, Ljubomir. Kholmskiy vopros. S.-Peterburg: Tip. Obshchestvennaya Pol'za, 1910.

Hugo, Abel. France pittoresque ou description pittoresque, topographique et statistique des départements et colonies de la France. Paris: Delloye, 1835. 
Izvestiya Imperatorskoy Arkheologicheskoy kommissii, pribavleniye k vypusku 14-mu, 33-34. S.-Peterburg, 1905.

K voprosu o vydelenii Kholmskoy Rusi. S.-Peterburg, 1906.

KARINSKIY, Nikolay Mikhaylovich. „Russkaya nadpis' v Lyublinskom tyuremskom kostele”. Izvestiya Imperatorskoy Arkheologicheskoy Kommissii, vyp. 55-y, 131-135. Petrograd, 1914.

Kazimierza Stronczyńskiego opisy i widoki zabytków w Królestwie Polskim (1844-1855), t. I: Ogólne Sprawozdanie Delegacji, oprac. J. Kowalczyk. Warszawa: Krajowy Ośrodek Badań i Dokumentacji Zabytków, 2009.

Kazimierza Stronczyńskiego opisy i widoki zabytków w Królestwie Polskim (1844-1855), t. V: Gubernia Lubelska, oprac. J. Teodorowicz-Czerepińska. Warszawa: Krajowy Ośrodek Badań i Dokumentacji Zabytków, 2014.

KEPPEN, Petr. Spisok russkim pamyatnikam, sluzhashchim ksostavleniyu istorii khudozhestva otechestvennoy paleografii. Moskva: Tipografiya S. Selivanovskago, 1822.

KoPerA, Feliks. „O malarstwie byzantyńskiem w Polsce”. Polskie Muzeum 1, z. 8 (1914): 1-3.

Korallov, Fedor Vasil'yevich. Tserkovno-arkheologicheskiy muzey pri Kholmskom Pravoslavnom Svyato-Bogoroditskom Bratstve. Kholm: Kholm. Sv.-Bogorodits. bratstvo, 1911.

KORALlOv, Fedor Vasil'yevich. „Pamyatnik drevne-russkoy ikonopisi,sokhranivshiysya v chasovne Sv. Troytsy goroda Lyublina". W Pamyatnaya knizhka Lyublinskoy gubernii na 1904 g. Lyublin: Gubernskaya tipografiya, 1904.

„Kratkiy otchet po tserkovno - arkheologicheskomu muzeyu i biblioteke pri nem za 1903904 bratskiy god". Kholmsko-Varshavskiy Yeparkhial'nyy Vestnik 19, nr 9 (27.II.1905): 112-113.

Kronprinzenwerk: Die österreichisch-ungarische Monarchie in Wort und Bild, red. J. Weil von Weilen, M. Jókai. Wien: Verlag der Kaiserlich-Königlichen Hof- und Staatsdruckerei, 1886-1902.

KryZHAnOvsKIY, S.M. „Slavyanskiy Krakov”. Drevnosti. Trudy Moskovskogo Arkheologicheskogo obshchestva 6 (1876): 120-134.

Literaturnaya kritika 1800-1820-kh godov, red. L.G. Frizman. Moskva: Khudozh. lit., 1980.

LoNGINOv, Aleksandr Sergeevich. „Pamyatniki russkoy stariny v g. Lyubline”. W Pamyatniki russkoy stariny, vyp. VIII: Kholmskaya Rus' (Lyublinskaya i Sedletskaya gub., Varshavskogo General-Gubernatorstva), red. P. Batyushkov. 209-260. S.-Peterburg: Izdaniye Ministerstva Vnutrennikh Diel, 1885.

„Lyublin”. W Entsiklopedicheskiy slovar Brokgauz-Efron, t. XVIII, 215-216. S.-Peterburg: AO «F.A. Brockhaus - I.A. Efron», 1896.

Lyublinskiye gubernskiye vedomosti, nr 263, 285, 287 (1903); nr 5 (1904).

ŁOPACIŃSKI, Hieronim. „Z powodu odkrycia zabytków malarstwa starożytnego w kościele świętej Trójcy w Lublinie". Gazeta Lubelska nr 67 (1904): 1-2; nr 68 (1904): 1-2; nr 69 (1904): 1-2.

ŁOPACIŃSKI, Hieronim. „Z puścizny naukowej po ś.p. Kazimierzu Stronczyńskim”. Wisła 17, z. 3 (1903): 349-352.

Nouveau voyage pittoresque de la France. Paris: Ostervald l'aîné, 1817.

„Otchet o sostoyanii i deyatel'nosti nakhodyashchegosya pod Vysochayshim Yego Imperatorskogo Velichestva pokrovitel'stvom Kholmskogo Pravoslavnogo Svyato-Bogoroditskogo bratstva za 1903-4 (dvadtsat' pyatyy) bratskiy god". Kholmsko-Varshavskiy Yeparkhial'nyy Vestnik 19, nr 10 (6.III.1905): 123-126.

Pamyatnaya knizhka Lyublinskoy gubernii na 1903 g. Lyublin: Gubernskaya tipografiya, 1903. 
PISAREV, Aleksandr Aleksandrovich. „Kiyevskiye drevniye pamyatniki”. W Zapiski i trudy Obshchestva istorii i drevnostey Rossiyskikh, uchrezhdennogo pri Imperatoskom Moskovskom universitete, ch. II, 144-166. Moskva: Universitetskoi tip., 1824.

PISAREV, Aleksandr Aleksandrovich. „Rech' o pol'ze otechestvennoy Arkheologii, proiznesennaya predsedatelem obshchestva Istorii i Drevnostey rossiyskikh 21 marta 1827 goda”. W Trudy i letopisi Obshchestva istorii i drevnostey Rossiyskikh, uchrezhdennogo pri Imperatoskom Moskovskom universitete, ch. IV, kn. I, 1-20. Moskva: Universitetskoi tip., 1828.

PISAREV, Aleksandr Aleksandrovich. „O drevnostyakh Novorossiyskogo kraya”. W Trudy i letopisi Obshchestva istorii i drevnostey Rossiyskikh, uchrezhdennogo pri Imperatoskom Moskovskom universitete, ch. V, kn. I. 192-214. Moskva: Universitetskoi tip., 1830.

PobedonostSEv, Konstantin Petrovich. Istoricheskaya zapiska o Kholmskoyrusi i gorode Kholme. $O$ sud'bakh unii $v$ Kholmskom kraye i sovremennom polozhenii $v$ nem uniatskogo voprosa. S.-Peterburg: Sinodal'naya tipografiya, 1902.

Poety-Radishchevstsy (A.Kh. Vostokov, I.P. Pnin, I.M. Born, V.V. Popugayev i drugiye poety Vol'nogo Obshchestva Lyubiteley Slovesnosti, Nauk i Khudozhestv), red. P.A. Orlov, G.A. Likhotkin. Leningrad: Sov. pisatel'., 1979.

Pogodin, Mikhail P. „Poslaniye k Polyakam (1861)”. W M.P. Pogodin, Pol'skiy vopros. Sobraniye rassuzhdeniy, zapisok $i$ zamechaniy, 1831-1867, 65-74. Moskva: V tipografii gazety «Russki», 1868.

PYPIN, Aleksandr N. Kharakteristiki literaturnykh mneniy ot dvadtsatykh do pyatidesyatykh godov. S.-Peterburg: Tip. M.M. Stasiulevicha, 1873.

„Rech', proiznesennaya Grafom D.A. Tolstym v Varshave, 12 sentyabrya 1868 goda”. Zhurnal Ministerstva Narodnogo Prosveshcheniya 139 (1868): 383-386.

S.C. [Czechowicz, Józef]. „Stary i nowy Lublin. Krótki przewodnik po naszym mieście”. dodatek do Expressu Lubelskiego: „Kalendarz na rok 1928”.

Scriptores: pamięć, miejsce, obecność: laboratorium pamięci, małe ojczyzny, spotkania kultur $\mathrm{nr} 32$ (2008): CZECHOWICZ - w poszukiwaniu ukrytego miasta. cz. 3.

SIDOrov, Aleksey Alekseevich. Russkiye i russkaya zhizn'v Varshave (1815-1895). Varshava: Tip. Gub. pravl., 1899.

SMOLIŃSKI, Józef. „Freski w kaplicy zamkowej w Lublinie”. Sprawozdania Komisji do Badania Historii Sztuki w Polsce 7 z. 4 (1905): szp. cclxvii-cclxviii.

SNegIRYov, Ivan Mikhaylovich. Pamyatniki Moskovskoy drevnosti, s prisovokupleniyem ocherka monumental'noy istorii Moskvy i drevnikh vidov i planov drevney stolitsy. Moskva: Izd. A. Semena, 1842-1845. [СНегиРев, Иван Михайлович. Памятники Московской древности, с присовокуплением очерка монументальной истории Москвы и древних видов и планов древней столицы. Москва: тип. А. Семена, 1842-1845].

SNEGIRYOV, Ivan Mikhaylovich. Russkaya starina v pamyatnikakh tserkovnogo i grazhdanskogo zodchestva. Moskva: V Politseyskoy tip., 1848-1860. [СНЕГИРЕВ Иван Михайлович. Русская старина в памятниках иерковного и гражданского зодчества. Москва: В Полицейской тип., 1848-1860].

SoBolEvSKIY, Aleksey Ivanovich. Russkiye freski v Staroy Pol'she. Moskva: Tovarishchestvo Tipografiya A.I. Mamontova, 1916.

SONEVITSKIY, Ivan Ivanovich. Kholmshchina. Ocherki proshlogo. S.-Peterburg: Tip. A.S. Suvorina, 1912.

Sprawozdania Komisji do Badania Historii Sztuki w Polsce 8 (1912). 
StorozhenKo, Andrey Vladimirovich. „Drevnosti g. Lyublina”. W Chteniya $v$ Istoricheskom Obshchestve Nestora Letopistsa, kn. 19, otd. II, vyp. 2-oy, 35-49. Kiyev: Tipo-litografiya T.G. Meinander, 1906.

Storozhenko, Andrey Vladimirovich. Malaya Rossiya ili Ukraina?. Rostov nad Donem, 1919.

Storozhenko, Andrey Vladimirovich. Proiskhozhdeniye i sushchnost' ukrainofil stva. Kiyev: Tipografiya S.V. Kul'zhenko, 1912.

STRONCZYŃSKI, Kazimierz. „Opisy zabytków starożytności przez Delegację wysłaną z polecenia Rady Administracyjnej Królestwa, zebrane w Guberni Lubelskiej w latach 1844 i 1846". Dziennik Powszechny nr 114 (21 maja 1863): 463-464.

STRUKOv, Dmitriy. Al'bom risunkov. 1864-1867, red. O.D. Bazhenova. Minsk: BelEn, 2011.

SumTsov, Nikolay Fedorovich. Iz ukrainskoy stariny. Khar'kov: «Pech. Delo» kn. K.N. Gagarina, 1905.

Teka Michała Kuleszy: zbiór widoków krajowych rysowanych z natury, Poszyt pierwszy. Paryż: Imprimerie Lemercier, 1852.

Voyages pittoresque et romantiques dans l'Ancienne France, red. Ch. Nodier, I. Taylor, A. de Cailleux. Paris: P. Didot l'ainé, etc., 1820-1878.

Widoki zabytków Starożytności w Królestwie Polskim stużace do objaśnienia Opisu tychże Starożytności sporzadzonego przez Delegację wysłana z polecenia Rady Administracyjnej Królestwa w latach 1852 i 1853 zebrane. Atlas VI. Gubernia Lubelska, Powiat Lubelski. Warszawa, 1855.

WILCZYŃSKI, Jan Kazimierz. Album wileńskie. Paryż, 1842-1875.

Zhivopisnaya Rossiya. Otechestvo nashe v yego zemel'nom, istoricheskom, plemennom, ekonomicheskom i bytovom znachenii, red. P.P. Semenov, t. I-XII. S.-Peterburg-Moskva: Izd. M.O. Wolfa, 1881-1901.

\section{OPRACOWANIA}

ADAMEK, Tadeusz. „Kaplica zamkowa św. Trójcy w Lublinie i jej polichromia”. W Lublin w dziejach i kulturze Polski, red. T. Radzik, A. Witusik, 51-60. Lublin: PTH Oddział w Lublinie, Krajowa Agencja Wydawnicza, 1997.

AL'TSHUlleR, Mark. Beseda lyubiteley russkogo slova: u istokov russkogo slavyanofil'stva. Moskva: Novoye Literaturnoye Obozreniye, 2007.

ANDERSON, Benedict. Wspólnoty wyobrażone. Rozważania o źródlach i rozprzestrzenianiu się nacjonalizmu, przekł. S. Amsterdamski. Kraków-Warszawa: Społeczny Instytut Wydawniczy, 1997.

BILEwicz, Hubert. „Między Krakowem a Petersburgiem. Casus bizantyńsko-ruskich malowideł lubelskich w pierwszych dekadach XX wieku”. W Kaplica Trójcy Świętej na Zamku Lubelskim. Historia, teologia, sztuka, konserwacja. Materiaty sesji zorganizowanej w Muzeum Lubelskim 24-26 kwietnia 1997 roku, red. B. Paprocka, J.A. Sil, 175-207. Lublin: Muzeum Lubelskie, PTTK Oddział w Lublinie, 1999.

BŁachowsKa, Katarzyna. Wiele historii jednego państwa. Obraz dziejów Wielkiego Księstwa Litewskiego do 1569 roku w ujęciu historyków polskich, rosyjskich, ukraińskich, litewskich i białoruskich w XIX wieku. Warszawa: Neriton, 2009.

BoŃCZA-TOMAsZEwSKI, Nikodem. „Polskojęzyczni chłopi? Podstawowe problemy nowoczesnej historii chłopów polskich”. Kwartalnik Historyczny 112, nr 2 (2005): 91-111.

BOYARCHENKOv, Vladislav Viktorovich „Nauka russkikh drevnostey v pervoy polovine XIX v.”. W Nauki o cheloveke. Istoriya distsiplin, red. A.N. Dmitriyev, I.M. Savel'yeva, 157-186. Moskva: Izd. dom Vysshey shkoly ekonomiki, 2015. 
BuczKowa, Irena. Kościót św. Trójcy na Zamku Lubelskim. Lublin: Muzeum Okręgowe w Lublinie, 1983.

BuczKowA, Irena. Zamek Lubelski. Lublin: Muzeum Okręgowe, 1969.

CHACHAJ, Jacek. „Czas podjęcia budowy wieży zamkowej w Lublinie w świetle najnowszych badań archeologicznych". Kwartalnik Historii Kultury Materialnej 67, nr 3 (2019): 307-322.

DolBILov, Mikhail Dmitrievich. Russkiy kray, chuzhaya vera: Etnokonfessional'naya politika imperii $v$ Litve i Belorussii pri Aleksandre II. Moskva: Novoye Literaturnoye Obozreniye, 2010.

DubBINI, Renzo. Geografie dello sguardo. Visione e paesaggio in età moderna. Torino: Einaudi, 1994.

DubBInI, Renzo. Geography of the Gaze. Urban and Rural Vision in Early Modern Europe. Chicago: University of Chicago Press, 2002.

FEDORUK, Aleksander. „Ukraina oczami Napoleona Ordy”. W Napoleon Orda 1807-1883. Materiały międzynarodowej konferencji naukowej poświęconej 200. rocznicy urodzin artysty, 23-30. Brześć: Konsulat Generalny RP w Brześciu, 2007.

GIERGIEL, Tomisław i Ptak Jan. „Fryz heraldyczny odkryty w katedrze sandomierskiej”. Rocznik Polskiego Towarzystwa Heraldycznego nowej serii nr 10 (21) (2011): 3-38.

GIRAUDO, Gianfranco. „Bayer et Tatiščev: l'histoire comme érudition ou comme service de l'Etat”. Europa Orientalis 5 (1986): 351-371.

GIRAUDO, Gianfranco. „La traduzione veneziana della Istorija gosudarstva rossijskogo (note bibliografiche e lessicografiche)”. W Profili di Storia veneta. Sec. XVIII-XX, red. U. Corsini, 95-128. Venezia: Università degli Studi - Ca' Foscari, 1985.

GIRAUDO, Gianfranco. „L’Ucraina e gli Ucraini dal passato al futuro”. Studi Slavistici 1 (2004): 25-33.

GŁĘBOCKI, Henryk. Fatalna Sprawa. Kwestia polska w rosyjskiej myśli politycznej (1856-1866). Kraków: Arcana, 2000.

GŁĘBOCKI, Henryk. „Irredenta polska a kresy Imperium. Powstanie Styczniowe (1863-1864) a ewolucja polityki Imperium Rosyjskiego wobec jego zachodnich »okrain«”. W H. GŁĘBOCKI. Kresy Imperium. Szkice i materiały do dziejów polityki Rosji wobec jej peryferii (XVIII-XXI), 306-363. Kraków: Arcana, 2006.

GORIZONTOV, Leonid Yefremovich. „Bol'shaya russkaya natsiya v imperskoy i regional'noy strategii samoderzhaviya". W Prostranstvo vlasti: istoricheskiy opyt Rossii i vyzovy sovremennosti, red. B.V. Ananich, S.I. Barzilov, 129-150. Moskva: Moskovskj obshchestvennyij nauchnyij fond, 2001.

GURBA, Stanisław. „Zagadnienie recepcji bizantyńsko-ruskich malowideł bazyliki Sandomierskiej w epokach późniejszych”. Studia Sandomierskie 21 (2014): 189-203.

Kaplica Trójcy Świętej na Zamku Lubelskim. Historia, teologia, sztuka, konserwacja. Materiaty sesji zorganizowanej w Muzeum Lubelskim 24-26 kwietnia 1997 roku, red. B. Paprocka, J.A. Sil. Lublin: Muzeum Lubelskie, PTTK Oddział w Lublinie, 1999.

KAPPELER, Andreas. Rußland als Vielvölkerreich. Entstehung, Geschichte, Zerfall. München: C.H. Beck, 1992.

KoZIARSKA-KowALIK, Janina. Kaplica Zamkowa w Lublinie. Lublin: Muzeum Lubelskie w Lublinie, 1997.

KRUK, Mirosław P. „Malowidła Graeco opere fundacji Jagiellonów jako postulat unii państwowej i kościelnej oraz jedności Kościoła”. W Między teologia a duszpasterstwem powszechnym na ziemiach Korony doby przedtrydenckiej. Dziedzictwo średniowiecza i wyzwania XV-XVI wieku, red. W. Walecki, 145-201. Warszawa: Wydawnictwo Uniwersytetu Warszawskiego, 2017. 
KucharzewsKi, Jan. Epoka Paskiewiczowska. Losy oświaty. Warszawa-Kraków: Gebethner \& Wolff, 1914.

KURAŚ, Stanisław. „Kiedy zbudowano okrągłą wieżę Zamku lubelskiego?”. W Problemy historii i archiwistyki, red. T. Mencel, 13-14. Lublin: Wydawnictwo UMCS, 1986.

KuRZĄTKOWSKI, Mieczysław. „»Album Lubelskie« Adama Lerue’a a »Inwentaryzacja Stronczyńskiego«". Przeglad Lubelski 1 (1965): 147-176.

KURZĄTKOWSKI, Mieczysław. ,»Album Lubelskie« Adama Lerue jako źródło ikonograficzne”. W Ikonografia dawnego Lublina, red. Z. Nestorowicz, 52-57. Lublin, 2000.

KUTYŁOwSKA, Irena. „Nowe spojrzenie na dzieje Zamku lubelskiego w średniowieczu”. Region Lubelski $\mathrm{nr} 2$ (4) (1987): 153-162.

LISAI, Yulia. „Pejzaże Napoleona Ordy - Narodowy koloryt międzynarodowej weduty”. W Napoleon Orda (1807-1883): ilustrowana encyklopedia kraju. Wystawa z kolekcji Muzeum Narodowego w Krakowie w Narodowym Muzeum Sztuki Republiki Białorusi, 15-19. Kraków: Muzeum Narodowe w Krakowie, 2017.

LOTMAN, Yuriy Mikhaylovich. „Arkhaisty-prosvetiteli”. W Iz istorii russkoy kul tury, t. V (XIX vek), red. A.D. Koshelev, B.F. Yegorov, 410-428. Moskva: Yazyki russkoy kul'tury, 1996.

ŁuCZEwski, Michał. Odwieczny naród. Polak i katolik w Żmiącej. Toruń: Wydawnictwo Naukowe UMK, 2012.

MAKAREWICZ, Stanisław W. „Fundacja i założenia programowe polichromii bizantyńskiej z bazyliki katedralnej w Sandomierzu". Studia Theologica Varsaviensia 13, nr 2 (1975): 117-148.

MASOERO, Alberto. „Linee di frattura nell'Impero zarista. Uno sguardo d'insieme”. Storica 17, nr 50 (2011): 7-66.

MAsoero, Alberto. „L'insostenibile lentezza dell'Impero zarista. Catasti e arte del governo in Transbaikalia”. Rivista Storica Italiana 130, fasc. 1 (2018): 118-163.

MAYOFIS, Maria. Vozzvanie k Yevrope: Literaturnoye obshchestvo "Arzamas" i rossiyskiy modernizatsionnyy proyekt 1815-1818 godov. Moskva: Novoye Literaturnoye Obozreniye, 2008.

Miller, Aleksey. Imperiya Romanovykh i natsionalizm. Esse po metodologii istoricheskogo issledovaniya. Moskva: Novoye Literaturnoye Obozreniye, 2006.

Miller, Alexei. „'Official Nationality’?: A Reassesment of Count Sergei Uvarov's Triad in the Context of Nationalism Politics". W A. MiLler. Romanov Empire and Nationalism: Essays in the Methodology of Historical Research, 139-160. Budapest-New York: Central European University Press, 2008.

MiLler, Aleksey Il'ich. „Tema Tsentral'noy Yevropy: istoriya, sovremennyye diskursy i mesto v nikh Rossii". Novoye literaturnoye obozreniye 52, nr 6 (2001): 75-96.

MILLER, Aleksey. "Ukrainskiy vopros" v politike vlastey i russkom obshchestvennom mnenii (vtoraya polovina XIX v.). S.-Peterburg: Alateija, 2000.

NAYT, Nataniel'. „Nauka, imperiya i narodnost': Etnografiya v Russkom geograficheskom obshchestve, 1845-1855". W Rossiyskaya imperiya $v$ zarubezhnoy istoriografii. Raboty poslednikh let: Antologiya, red. P. Vert, P.S. Kabytov, A.I. Miller, 155-198. Moskva: Novoe izdvo, 2005

NowAK, Andrzej. „Pod kopytami Miedzianego Jeźdźca - „geopoetyka” rosyjska i Polska”. W A. Nowak. Metamorfozy Imperium Rosyjskiego 1721-1921. Geopolityka, ody i narody, 19-74. Kraków: Wydawnictwo Literackie, 2018.

OsADCZY, Włodzimierz. Święta Ruś. Rozwój i oddziaływanie idei prawosławia w Galicji. Lublin: Wydawnictwo UMCS, 2007. 
PASZKIEWICZ, Piotr. W stużbie Imperium Rosyjskiego, 1721-1917. Funkcje i treści ideowe rosyjskiej architektury sakralnej na zachodnich rubieżach cesarstwa i poza jego granicami. Warszawa: Instytut Sztuki PAN, 1999.

PICCIN, Matteo. „Da "Scuola Superiore” a "Università Imperiale di Varsavia”: genesi di un'università russa nel Regno di Polonia (1862-1869)". Annali di Ca' Foscari 45, nr 1 (2006): 151-189.

PICCIN, Matteo. „Geografie wyobrażone rosyjskiego nacjonalizmu: gubernie zachodnie Imperium i „Ruś Chełmska” między tradycją a nowoczesnością myśli narodowej”. W Przypominać zapomniane, odkrywać nieznane. Polskie losy: Kościót - Syberia - Rosja (XIX-XX w.). Studia ofiarowane Profesorowi Eugeniuszowi Niebelskiemu w 70. rocznicę urodzin, red. A. Barańska, 205-224. Lublin: Towarzystwo Naukowe KUL, 2019.

PICCIN, Matteo. „Lieux de Mémoire na pograniczu polsko-ruskim. Przypadek Ziemi Chełmskiej (po 1863 r.)". Przeglad Środkowo-Wschodni 5 (2020): 9-43.

PrZeciszewska, Maria M. „Between Empire and Nation. The social function of books in the Kingdom of Poland, 1864-1914". Polish Libraries 7 (2019): 96-127.

PrZeCiszewsKA, Maria M. „Naród, imperium, narracja. Podręczniki do historii Dymitra Iłowajskiego jako narzędzie rosyjskiej „polityki czytelniczej” w Królestwie Polskim”. Slavia Orientalis 64, nr 1 (2015): 35-50.

PRZECISZEwSKA, Maria M. „»Tworzenie Rosjan«. Narodowotwórcza funkcja wybranych publikacji Bractwa Przenajświętszej Bogurodzicy w Chełmie (1884-1915)”. Rocznik Biblioteki Narodowej 48 (2017): 347-372.

RoKosZnY, Józef. Średniowieczne freski w katedrze sandomierskiej. Kraków: Akademia Umiejętności, 1914.

RÓŻYCKA-BrYZEK, Anna. „Bizantyńsko-ruskie malowidła ścienne w kaplicy Świętokrzyskiej na Wawelu (1470)". Studia do Dziejów Wawelu 3 (1968): 175-293.

RóżYCKA-BRYZEK, Anna. Bizantyńsko-ruskie malowidla w kaplicy zamku lubelskiego. Warszawa: Państwowe Wydawnictwo Naukowe, 1983.

RÓŻYCKA-BRYZEK, Anna. „Bizantyńsko-ruskie malowidła ścienne w kolegiacie wiślickiej”. Folia Historiae Artium 2 (1965): 47-82.

RóŻYCKA-BRYZEK, Anna. Freski bizantyńsko-ruskie fundacji Jagietly w kaplicy Zamku Lubelskiego. Lublin: Muzeum Lubelskie, Wydawnictwo UMCS, 2000; wyd. 2, red. M. Janik. Lublin: Muzeum Lubelskie, 2012

SCHILLER-WALICKA, Joanna. „Cesarski Uniwersytet Warszawski. Między edukacją a polityką 1869-1917". W Dzieje Uniwersytetu Warszawskiego 1816-1915, red. T. Kizwalter, P.M. Majewski, 556-703. Warszawa: Wydawnictwa Uniwersytetu Warszawskiego, 2016.

SHENK, Frit'of Ben'yamin. „Mental'nyye karty: konstruirovaniye geograficheskogo prostranstva v Yevrope ot epokhi Prosveshcheniya do nashikh dney". Novoye literaturnoye obozreniye 52, nr 6 (2001): 42-61.

Simosato, Tosiyuki. „Pereosmysleniye kontseptsii «narodnost'»: S.S. Uvarov kak konservativnyy myslitel". Mysl 20 (2016): 87-97.

SMORĄG-RÓŻYCKA, Małgorzata. „Bizantyńskie freski w sandomierskiej katedrze: królewski dar na chwałę Bożą czy odblask idei unii horodelskiej?”. Zeszyty Naukowe Uniwersytetu Jagiellońskiego. Prace Historyczne 141, z. 2 (2014): 235-255.

STALIŪNAS, Darius. „Assimilation or Acculturation? Russian Imperial Policy Toward Lithuanians in the 1860s". Central and Eastern European Review 2 (2008): 1-20. 
Staliūnas, Darius. Making Russians. Meaning and Practice of Russification in Lithuania and Belarus after 1863. Amsterdam-New York: Rodopi, 2007.

STAWICKI, Stanisław. „Przyczynki do historii ściennych malowideł bizantyjsko-ruskich w Polsce. Technika i konserwacja”. Ochrona zabytków nr 1/47 (184) (1994): 3-21.

SZABACIUK, Andrzej. Rosyjski Ulster. Kwestia chelmska w polityce imperialnej Rosji wobec Królestwa Polskiego w latach 1863-1915. Lublin: Wydawnictwo KUL, 2013.

SzWARC, Andrzej. „Akademia Medyko-chirurgiczna i Szkoła Główna 1857-1869”. W Dzieje Uniwersytetu Warszawskiego 1816-1915, red. T. Kizwalter, P.M. Majewski, 415-555. Warszawa: Wydawnictwa Uniwersytetu Warszawskiego, 2016.

WADOWSKI, Jan Ambroży. Kościoty lubelskie na podstawie źródel archiwalnych. Kraków: Akademia Umiejętności, 1907.

WALICKI, Andrzej. W kręgu konserwatywnej utopii. Struktura i przemiany rosyjskiego stowianofilstwa. Warszawa: Wydawnictwo Naukowe PWN, 2002.

WALICKI, Andrzej. Zarys myśli rosyjskiej. Od Oświecenia do Renesansu religijno-filozoficznego. Kraków: Wydawnictwo Uniwersytetu Jagiellońskiego, 2005.

WALICKI, Michał. „Malowidła ścienne kościoła św. Trójcy na zamku w Lublinie (1418)”. Studia do dziejów sztuki w Polsce 3 (1930): 1-92.

WALICKI, Michał. Sprawa inwentaryzacji zabytków w dobie Królestwa Polskiego (1827-1862). Warszawa: Kasa im. Mianowskiego, 1931.

Warszawska „Cyganeria” malarska. Grupa Marcina Olszyńskiego, oprac. S. Kozakiewicz, A. Ryszkiewicz. Wrocław: Zakład Narodowy im. Ossolińskich, 1955.

WeBER, Eugen. Peasants into Frenchmen. The Modernization of Rural France, 1870-1914. Stanford: Stanford University Press, 1976.

WeEks, Theodore R. Nation and State in Late Imperial Russia. Nationalism and Russification on the Western Frontier, 1863-1914. DeKalb: Northern Illinois University Press, 1996.

WeEks, Theodore R. „The „End” of the Uniate Church in Russia: The Vossoedinenie of 1875”. Jahrbücher für Geschichte Osteuropas 44, H. 1 (1996): 28-40.

WYRZYKOWSKI, Andrzej. „Zabytkowe freski w prezbiterium katedry sandomierskiej”. Kronika Diecezji Sandomierskiej 10 (1934): 277-287.

Zapadnyye okrainy Rossiyskoy imperii, red. M.D. Dolbilov, A.I. Miller. Moskva: Novoye Literaturnoye Obozreniye, 2006.

ZiARKowsKi, Dominik. „Inwentaryzacja zabytków Królestwa Polskiego a system ochrony dziedzictwa kulturowego w Rosji w pierwszej połowie XIX wieku". Sztuka Europy Wschodniej. Искусство Восточной Европы. Art of Eastern Europe 1 (2013): 193-205.

ZoRIN, Andrey. „Zavetnaya Triada. Memorandum S.S. Uvarova 1832 goda i vozniknoveniye doktriny „pravoslaviye - samoderzhaviye - narodnost”. W A. ZoRIN. Kormya dvuglavogo orla ... Literatura i gosudarstvennaya ideologiya $v$ Rossii v posledney treti XVIII-pervoy treti XIX veka, 337-374. Moskva: Novoye Literaturnoye Obozreniye, 2004. [ЗоРин Андрей, „Заветная Триада. Меморандум С.С. Уварова 1832 года и возникновение доктрины „православие - самодержавие - народность". W А. Зорин, Кормя двуглавого орла... Литература и государственная идеология в России в последней трети XVIII-первой трети XIX века, 337-374. Москва: Новое литературное обозрение, 2004]. 


\title{
SZTUKA W SŁUŻBIE IMPERIUM I NARODU: \\ CASUS BIZANTYJSKICH FRESKÓW W KAPLICY ŚW. TRÓJCY NA ZAMKU LUBELSKIM W ŚWIETLE POGLĄDÓW ROSYJSKICH HISTORYKÓW (XIX - POCZĄTEK XX WIEKU)*
}

\author{
Streszczenie
}

Celem niniejszego artykułu jest refleksja nad nacjonalizmem rosyjskim - jego znaczeniem i zasięgiem terytorialnym, realnym, a także wyobrażonym - w Królestwie Polskim na przełomie XIX i XX w. Jako case study autor wybrał znamienite bizantyjskie freski z początku XV w., które pokrywają wewnętrzne ściany kaplicy Świętej Trójcy na Zamku Lubelskim w Lublinie. Autor stawia sobie pytanie, czy Lublin, ze względu na obecność fresków szkoły ruskiej, odsłoniętych dopiero na początku XX w., był w rozumieniu rosyjskich nacjonalistów miastem o rodowodzie ruskim (rosyjskim) i miał w takim razie ulec rusyfikacji, której sąsiednia Chełmszczyzna doświadczała od co najmniej 30 lat. Gdzie więc była granica nacjonalizmu rosyjskiego? Lublin leżał na granicy z ziemią chełmską, a odkrycie malowideł mogło spowodować zasadniczą rewizję spojrzenia na to miasto jako miasto polskie.

Znani intelektualiści polscy, a także rosyjscy archeologowie, historycy i badacze starożytności wzięli udział w debacie wokół pochodzenia fresków i ich genezy. I wojna światowa przerwała wszelkie projekty prac konserwatorskich, a wraz z nimi także próby dalszego odsłaniania „,rosyjskości” Lublina.

Słowa kluczowe: Kaplica Świętej Trójcy na Zamku Lubelskim; Królestwo Polskie; imperium rosyjskie; nacjonalizm rosyjski; starożytności.

\section{ART IN THE SERVICE OF EMPIRE AND NATION THE CASE OF BYZANTINE FRESCOES OF THE HOLY TRINITY CHAPEL IN LUBLIN CASTLE THROUGH THE LENS OF RUSSIAN HISTORIANS (19TH - EARLY 20TH CENTURY)}

\section{Sum m a ry}

The purpose of this article is to reflect on Russian nationalism - its significance and territorial range, real and imagined - in the Kingdom of Poland at the turn of the 19th and 20th centuries. As a case study, the author chose the renowned Byzantine frescoes from the early 15 th century that cover the inner walls of the chapel of the Holy Trinity in the Lublin Castle. The author considers whether, due to the presence of Ruthenian frescoes, whose uncovering dates back to early 20th century, Russian nationalists understood Lublin as a "Russian" (Ruthenian) city, which would then need to undergo Russification (as had occurred in the neighbouring Chełm region for at least the previous 30 years). Where then was the border of Russian nationalism? Given Lublin's location on the border with the Chełm land, the discovery of the paintings could have caused a radical reassessment in the perception of the city as Polish.

Well-known Polish intellectuals, as well as Russian archaeologists historians and zealous seekers of antiquities took part in the debate about the origin of the frescoes and their attribution. The First World War interrupted all conservation projects, and with them any further attempt at unearthing Lublin's "Russiannes".

Keywords: Holy Trinity Chapel in Lublin Castle; Kingdom of Poland; Russian Empire; russian nationalism; antiquities. 